\title{
Viability of karezes (ancient water supply systems in Afghanistan) in a changing world
}

\author{
G. L. Macpherson ${ }^{1}$ (D) W. C. Johnson ${ }^{2} \cdot$ Huan Liu $^{1}$
}

Received: 13 April 2015/Accepted: 25 August 2015/Published online: 9 September 2015

(C) The Author(s) 2015. This article is published with open access at Springerlink.com

\begin{abstract}
The Afghanistan population living far from rivers relies upon groundwater delivered from karezes (sub-horizontal tunnels). Karezes exploit unconfined groundwater in alluvial fans recharged largely by snowmelt from the Hindu Kush, the central mountain range of the country. Since the multi-year drought that began in 1998, many karezes have stopped flowing. This study characterizes the hydraulics of a kariz, the potential for reduced groundwater recharge because of climate change, and the impact of increasing population on kariz water production. A typical kariz in Afghanistan is 1-2 km long with a crosssection of $1-2 \mathrm{~m}^{2}$ and gradient of $1 \mathrm{~m} \mathrm{~km}^{-1}$. MODFLOW simulations show that water delivery from a kariz can be modeled by imposing a high ratio of kariz hydraulic conductivity to aquifer hydraulic conductivity on the cells representing the kariz. The model is sensitive to hydraulic conductivity, kariz gradient, and length of the kariz in contact with the water table. Precipitation data are scarce in Afghanistan, but regional data show a long-term trend of decreased snow cover, and therefore strong likelihood of decreased aquifer recharge. Population in Afghanistan has increased at a rate of about $2.2 \%$ over the past several decades. An assessment of a six-district region within Kandahar Province where karezes are the most likely source of water indicates that water demand could have caused water tables to decline by $0.8-5.6 \mathrm{~m}$, more than enough to cause karezes to stop flowing. These results
\end{abstract}

G. L. Macpherson

glmac@ku.edu

1 Dept. of Geology, Univ. of Kansas, 1475 Jayhawk Blvd, Rm. 120 Lindley Hall, Lawrence, KS 66045, USA

2 Dept. of Geography, Univ. of Kansas, 1475 Jayhawk Blvd, Rm. 120 Lindley Hall, Lawrence, KS 66045, USA suggest that kariz water production is not sustainable under current climate- and population-growth trends.

Keywords Kariz - Qanat - Water resources ·

Arid regions $\cdot$ Climate change $\cdot$ Population growth

\section{Introduction}

Water in arid and semiarid regions is both a critical resource for human occupation and survival, and a technical challenge in efficient harvesting and transport. Water availability in dry regions is primarily limited by the very small amounts of meteoric precipitation that re-supply below-ground resources and snowmelt from nearby mountainous regions which is, in some regions, the primary source of recharge to aquifers through losing streams and rivers. Climate warming can affect stream flow and aquifer recharge if winter meteoric precipitation changes from snow pack that builds up during the winter months and melts slowly over the spring and summer, to rain that runs off immediately. This change can be accompanied by a reduction in the total amount of meteoric precipitation, exacerbating the water supply problem. Furthermore, in arid regions, because recharge is limited, depth to groundwater is characteristically large, such that accessibility to water is limited by economics and technology. In Afghanistan, affordable technology is commonly limited. Further, if groundwater can be brought to the land surface, technical challenges occur in moving the water to where it is needed because high evaporation rates typical of dry regions result in volume loss and increased salinity in the delivered water. Finally, as human population grows and occupies marginally productive land with greater need for

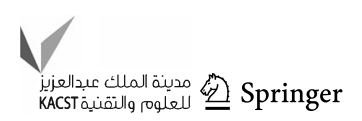


water, the sustainability of water use is challenged, and water becomes a non-renewable resource.

Arid regions of the Middle East, Asia, and Northern Africa have used, for centuries, water supply systems consisting of hand-dug tunnels in alluvial fan sediments near mountains that provide snowmelt-sourced groundwater (Fig. 1). These systems were initially developed in Persia, dating from 3000 years ago (Mays 2008), and dispersed to the east, west, south and north. The structures were cleverly designed to minimize evaporative loss by harvesting underground water through tunnels, with delivery close to areas of use. Names for these structures vary with region (Table 1), but because the focus of this study is western Afghanistan, they are herein called karezes (kariz, singular). No matter the name, these structures have similar characteristics: a sub-horizontal, slightly sloping tunnel that taps the water table, generally in an alluvial fan aquifer proximal to the mountain range; vertical shafts (chahs) used for initial tunnel construction, maintenance access and aeration; and water delivery to the land surface near the point of use more distal in the alluvial fan. Karezes have been traditionally installed and maintained without mechanized devices and they deliver water by gravity alone, making them a relatively inexpensive water source especially adapted for rural water supply and irrigation in developing countries. The highest discharge from karezes occurs in the spring and early summer, when crops require irrigation, and the least discharge occurs in the late fall and
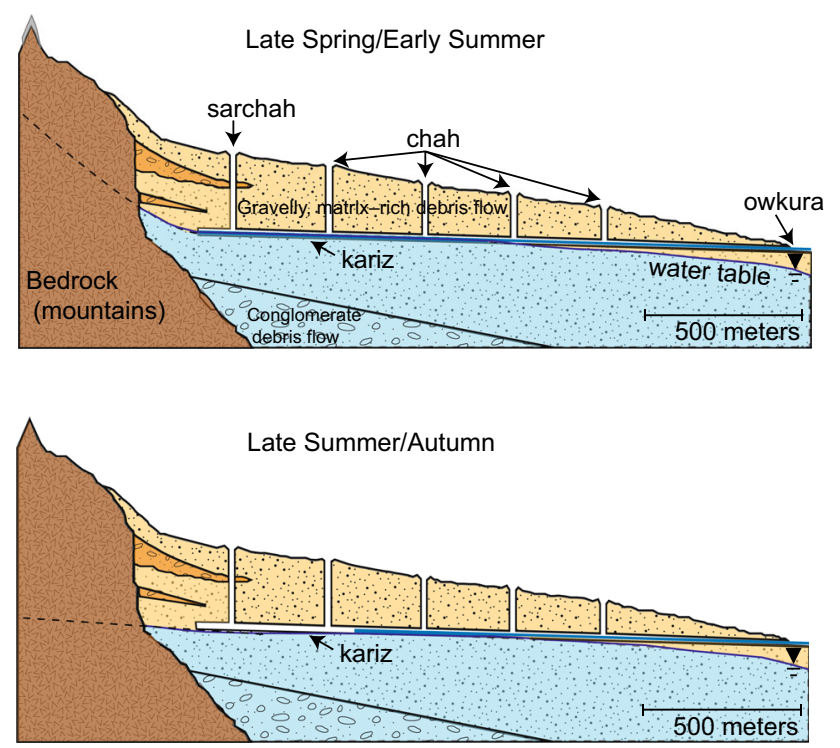

Fig. 1 Conceptual diagram of a functioning kariz, showing the subhorizontal tunnel following the water table of the aquifer, except at the downstream end, where seepage loss may be substantial. Aquifer water table is higher in the spring and early summer than the fall and winter, making the length of the kariz in contact with the water table longer in the spring and early summer winter, when irrigation water is less needed, making them relatively efficient (e.g., Beaumont 1989). These structures have an advantage over surface water sources in many areas of Afghanistan, because the surface water sources are often dry during all or parts of August-November due to less snowmelt and extensive diversion for irrigation (ERDC 2002). Karezes can be clearly seen in Google Earth and in low-altitude imagery of Afghanistan (Fig. 2).

Recent reports of numbers of Afghanistan karezes no longer yielding water vary, but all agree that significant numbers of karezes and shallow wells are going dry or producing less water. This trend has also been reported for other countries (e.g., Remini et al. 2014). Shobair (2002) reported that all traditional irrigation systems in Afghanistan (karezes and structures diverting river water) have experienced reduced flow or complete drying, with $60-70 \%$ of karezes and $85 \%$ of shallow wells completely dry. In addition, water levels were observed to be falling 0.5-3 meters (m) per month. Shobair and Alim (2004) reported $36 \%$ of karezes dry and the remaining operating karezes with flow reduced as much as $83 \%$. In the Kabul Basin of Afghanistan, water-table declines have been attributed to groundwater withdrawals with inadequate recharge, and rises to recharge following a drought period (Mack et al. 2010b, 2013). Non-uniform decline is not uncommon in heavily used aquifers (e.g., McGuire 2012). In the Kandahar area, the general area investigated in this project, comparison of water-level measurements from the early 1970s with those in 2003 reveals water-table declines of about 6-20 m in all six wells reported (CDM 2003).

Water sources, including rivers and constructed reservoirs in southern and southwestern Afghanistan and ground- and surface water in the Kabul Basin, have been studied recently by the US Geological Survey. The Helmand River and its tributaries, a closed-basin desert river that drains about $40 \%$ of the country (Whitney 2006; Shroder 2014) and supplies the Kandahar area with some of its water, traverses much of western and southern Afghanistan from west to east, staying south of the Hindu Kush. The Helmand River results from the confluence of a series of rivers (Uhl and Tahiri 2003; Whitney 2006; Shroder 2014). From west to east, the Arghastan and Tarnak Rivers converge to form the Dori River, which in turn joins the Arghandab River southwest of Kandahar, and the Arghandab River then joins the Helmand River. The alluvium associated with these rivers hosts many karezes. Modeling of water in the upper (Whitney 2006) and lower (Vining and Vecchia 2007) Helmand River basins has shown the susceptibility of surface water sources to drought, sedimentation, and increasing water demand, but neither of these studies included modeling of groundwater. Relatively recent studies in the Kabul Basin, north and east of the study area, have been completed by Mack et al. 
Table 1 Lexicon: selected terms related to kariz-type groundwater supply systems

\begin{tabular}{|c|c|c|c|}
\hline Term & Where term is used & Definition & Citation \\
\hline Karez & Afghanistan & & Hussain et al. 2008 \\
\hline Karez & Northern Iraq & Kurdish word, also means "working in one line" & Lightfoot 2009 \\
\hline Karez & Pakistan & & Hussain et al. 2008 \\
\hline Kahrez & Persia & & Lightfoot 2009 \\
\hline Bir al-umm & Northern Iraq & Mother well & Lightfoot 2009 \\
\hline Neqba & Northern Iraq & Shafts to karez & Lightfoot 2009 \\
\hline Lagham & Northern Iraq, around Erbil & The horizontal tunnel (Kurdish word meaning underground tunnel) & Lightfoot 2009 \\
\hline Loyin & Northern Iraq, around Erbil & Tunnel between two shafts & Lightfoot 2009 \\
\hline Kuna kotor & Northern Iraq, around Erbil & $\begin{array}{l}\text { "Kurdish kun }=\text { hall and kotor }=\text { a type of bird that goes into karez } \\
\text { channels for water; i.e., "hall of the kotor bird"" }\end{array}$ & Lightfoot 2009 \\
\hline Kala bir & Iraqi Kurdistan & Source well or mother well (translated: "big well") & Lightfoot 2009 \\
\hline Bira gumana & Iraqi Kurdistan & $\begin{array}{l}\text { "checking well". The well where you check to see if there is enough } \\
\text { water to dig a karez. }\end{array}$ & Lightfoot 2009 \\
\hline Tayan & Iraq & First section of the karez, near the mother well & Lightfoot 2009 \\
\hline Manjal & Iraq & Last well before the exit & Lightfoot 2009 \\
\hline Killil & Iraq & Karez exit point (translated as "key" in Kurkish) & Lightfoot 2009 \\
\hline Miftah & Iraq & Karez exit point (translated as "key" in Arabic) & Lightfoot 2009 \\
\hline Zari karez & Iraq & Karez exit point (translated as "mouth of the karez" in Kurdish) & Lightfoot 2009 \\
\hline Astelik & Iraq & Basin or cistern at the end of the karez & Lightfoot 2009 \\
\hline Kariz & Western Afghanistan & Persian term for qanat of Iran & McLachlan 1989 \\
\hline Mambo & Japan & Similar to karez & McLachlan 1989 \\
\hline Sarchah & Afghanistan & Mother well & Rout 2008 \\
\hline Chah & Afghanistan & Access wells to karez & Rout 2008 \\
\hline Hawz & Afghanistan & $\begin{array}{l}\text { Temporary water storage (basin) for karez-discharged water } \\
\text { (overnight or to increase flow distribution rates) }\end{array}$ & Rout 2008 \\
\hline Qanat & Iran & Similar to karez & Rout 2008 \\
\hline Falaj & Oman & Similar to karez & Rout 2008 \\
\hline Foggaras & North Africa & Similar to karez & Rout 2008 \\
\hline Owkura & Afghanistan & Outflow point or access point of karez water & Rout 2008 \\
\hline Qanat & Iran & Similar to karez & Hussain et al. 2008 \\
\hline Ain & Saudi Arabia & Similar to karez & Hussain et al. 2008 \\
\hline Felaj/aflaj & United Arab Emirates & Similar to karez (singular/plural) & Hussain et al. 2008 \\
\hline Felaj/aflaj & Oman & Similar to karez (singular/plural) & Hussain et al. 2008 \\
\hline Kanerjing & China & Similar to karez & Hussain et al. 2008 \\
\hline Qanat romani & Jordan & Similar to karez & Hussain et al. 2008 \\
\hline Qanat romani & Syria & Similar to karez & Hussain et al. 2008 \\
\hline Khettara & Morocco & Similar to karez & Hussain et al. 2008 \\
\hline Mother well & Baluchistan (Pakistan) & A well of karez, yielding water & Kahlown et al. 1988 \\
\hline Lamboor & Baluchistan (Pakistan) & Local name for karez tunnel & Kahlown et al. 1988 \\
\hline Galeria & Spain & Similar to karez & Hussain et al., 2008 \\
\hline Foggara/fughara & North Africa & French translation of "qanat" & Cressey 1958 \\
\hline
\end{tabular}

(2010a), Broshears et al. (2005), Houben et al. (2009a, b), Akbari et al. (2007) and Tünnermeier et al. (2005). These studies characterized the aquifers, modeled the hydrology, and characterized the water chemistry of the Kabul Basin. The Kabul Basin is hydrologically distinct from the Kandahar-area aquifers and rivers, draining to the east rather than the south and west. The Kabul Basin has a fairly large population, and the groundwater in places has shown major declines due to high demand (Mack et al. 2010a, 2013).

This study presents a preliminary investigation of how karezes function to produce water, their geology and landscape position, and an initial assessment of the viability of these structures in southern and southwestern Afghanistan in an era of warming climate, frequent drought 

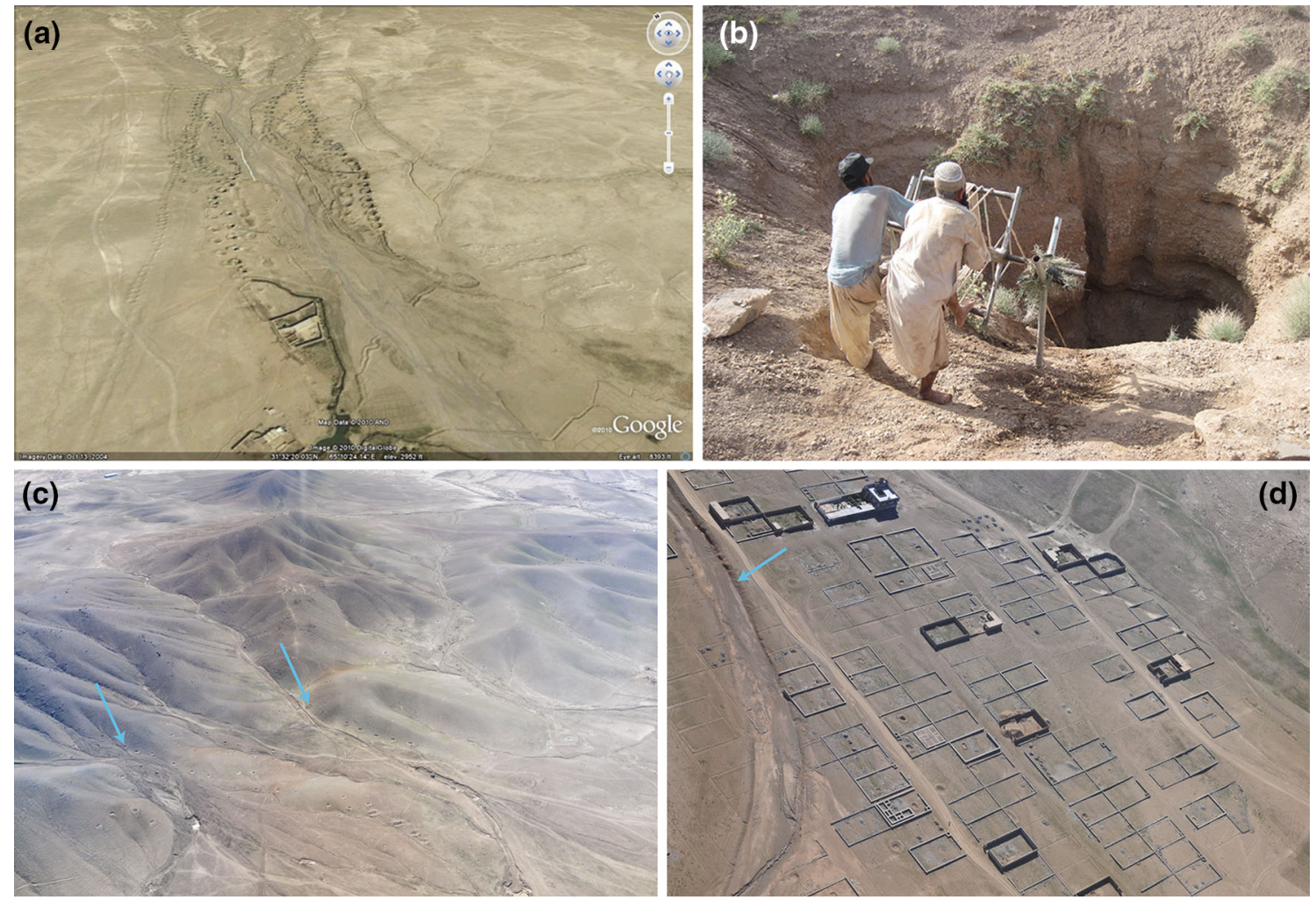

Fig. 2 Remote imaging of karezes. a Enhanced Google Earth image of a kariz, showing the vertical access shafts (chahs) and outflow channel leading to irrigated farms. b Afghans service an active kariz near Shindand Air Base, 7 miles northeast of Sabzwar, Herat Province, Afghanistan. Image credit, Chad Nichols. c Low-angle aerial view of chahs in the foothills of the Hindu Kush, Afghanistan.

and population growth. A major challenge to this project was obtaining quantitative, site-specific supporting data in this re-emerging country that has been in military and internal conflict since 1973. As a consequence of these difficulties, outcomes are general results. Nevertheless, the modeling shows a general representation of groundwater flow to a kariz, and we use the generalized aquifer characteristics to estimate of the effect of climate change and population growth on sustainability of kariz-produced groundwater use.

\section{Setting}

The study area is southwestern Afghanistan, Helmand Province, in the vicinity of Kandahar (Fig. 3a). In Afghanistan, the Hindu Kush mountain range, the western extension of the Himalayas, splits the country into a slightly more humid northern and northeastern region and a more arid western, southern, and eastern region. The Hindu Kush has historically trapped snow from weather fronts moving inland from the Mediterranean Sea in the winter and from the Indian
Arrows point to two of the sarchahs (most upgradient chah of the kariz). Image credit, Petty Officer First Class Bill Steele, USN Reserve. d Low-angle aerial view of a walled village with walled agricultural fields, showing the canal from a kariz that supplies water to the village. Also visible are chahs within the village. Image credit, Petty Officer First Class Bill Steele, USN Reserve

Ocean in the summer (Favre and Kamal 2004). Most of Afghanistan, however, only receives winter precipitation (Syed et al. 2006), with only the easternmost portions of Afghanistan benefiting occasionally from the remnants of the Indian summer monsoon. Besides mountain snow, during the winter season the most effective liquid precipitation falls gently during the "Chel-i Buzurg" or "big 40 days" starting about 21 December; heavier rainfall starting near the end of February can cause flash flooding that contributes little to groundwater recharge (Favre and Kamal 2004).

Data used to approximate the geometry of the karezes, the method used to assess their landscape positions in alluvial fans adjacent to the Hindu Kush, the general geology of those alluvial fans, and data for meteoric precipitation that provides recharge to the alluvial fan aquifers are described next, along with sources of information about population trends in Afghanistan and a summary of climate change predictions for the region. Together, these factors are used to make a first approximation of groundwater delivery to a kariz, and to consider how climate change and population growth have impacted groundwater resources in the recent past and how it might impact them in the future. 
(a)

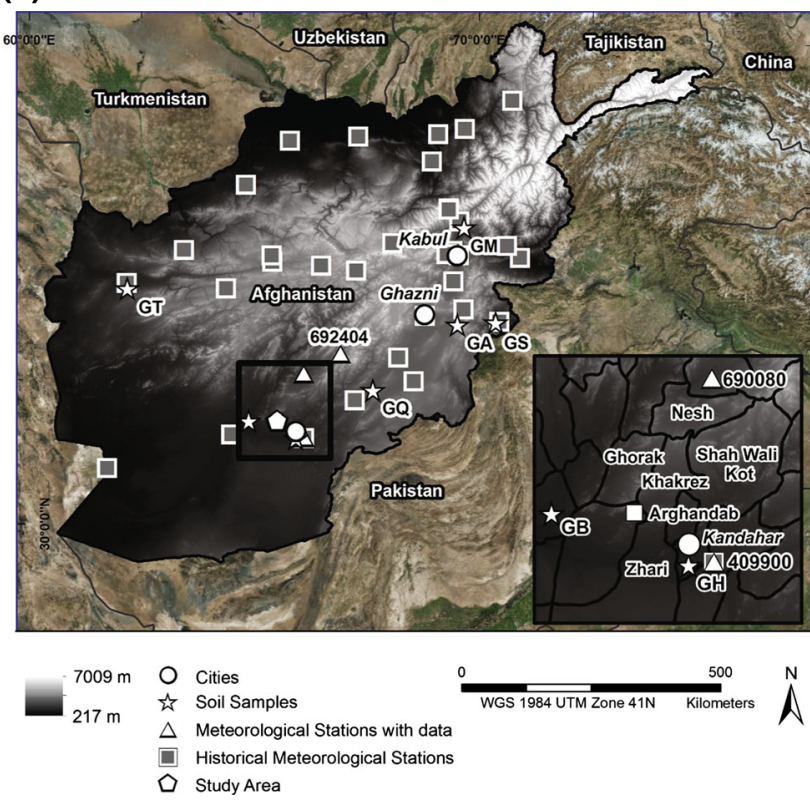

(b)

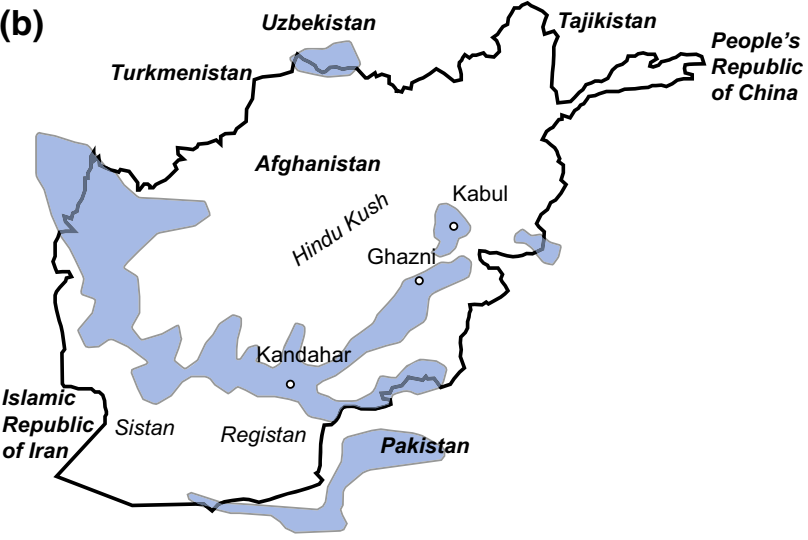

Fig. 3 Selected features of Afghanistan. a Topography (gray scale), major cities in eastern and southern Afghanistan (white-filled circles), historic meteorological stations (Favre and Kamal 2004; whiteoutlined, gray-filled squares), meteorological stations with data used in this study (NOAA Climate.gov; white-filled triangles with NOAA identification number), soil sample localities (white-filled stars). Wells with $K_{\mathrm{h}}$ from pumping tests (see text) are near the cities of Kandahar (CDM 2003) and Kabul (Tünnermeier et al. 2005); whitefilled pentagon is location of study area in Fig. 4. Inset shows Districts of Kandahar province used in the estimate of increased water consumption shown in Fig. 12 (see text). This map was built with ArcGIS, using data from the following sources. World Imagery Basemap: Esri, DigitalGlobe, GeoEye, i-cubed, Earthstar Geographics, CNES/Airbus DS, USDA, USGS, AEX, Getmapping, Aerogrid, IGN, IGP, swisstopo, and the GIS User Community. DEM overlay of Afghanistan: ASTER GDEM, a product of METI and NASA (https:// lpdaac.usgs.gov). Afghanistan country and district borders: GADM database (www.gadm.org), version 2.0, December 2011, and Afghanistan Information Management Services (AIMS). World borders: (http://thematicmapping.org/). b Blue shaded areas show general distribution of kariz irrigation systems in and adjacent to Afghanistan (modified from Humlum 1959)

\section{Methods and data}

Finding quantitative, site-specific data for model-input parameters and outcome interpretations in Afghanistan is a challenge similar to those faced in other countries (e.g., Silliman et al. 2007). Consequently, some generalizations were made. The methods for identifying karezes in the landscape, the sources of data and choices of groundwater model inputs, and the sources of information about population trends are described in this section.

\section{Kariz locations}

In Afghanistan, most of active and abandoned karezes are located on the eastern, southern and western flanks of the Hindu Kush (Fig. 3b). In a study of a local area (Fig. 3a), an algorithm was designed to automatically locate chahs in a GIS environment. First, visual identification of kariz features (vertical access shafts or chahs) was made using orthophotography and the locations entered in a GIS environment. Karezes in Afghanistan exhibit a surface expression of roughly circular depressions ringed by piles of sediment, chahs, that lead to a surface canal delivering water to a village (Figs. 1,2). Active and abandoned chahs were distinguished by considering whether the holes appeared open or collapsed.

Second, the fill-function of the ArcGIS Hydro Tools was used to demarcate the circular depression within the chahs, as rendered in a LiDAR-derived, digital elevation model (Fig. 4a). After filtering the depression recognition data to remove extraneous negative features, results of this approach to chah mapping agreed well with that obtained from visual (manual) identification. This approach to chah identification and mapping was augmented with first-return LiDAR data (Fig. 4b). Fuchsia-colored polygons in the lower left-hand part of the image indicate positive features identified by the first-return of the LiDAR laser pulsing. These features recognized are trees growing (planted) along surface irrigation canals fed by the kariz. An additional aspect of this use of ArcGIS depression rendering is that abandoned chahs can be identified if any LiDAR-detectable depression still persists. This is exemplified by the straight reach of faint, abandoned chahs circumvented to the left (west) by a replacement conduit system (Fig. 4b).

\section{Hydraulic conductivity $\left(K_{h}\right)$ of alluvial fan sediments hosting karezes}

Over most of non-mountainous Afghanistan, soil samples to a depth of $\sim 1.5 \mathrm{~m}$ in alluvial materials were collected and grain size analyses completed (J. Kelley, personal 


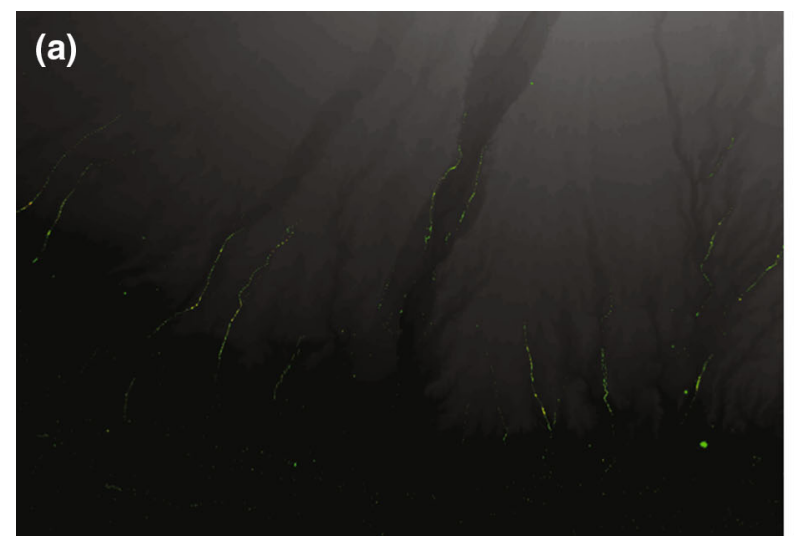

Fig. 4 Lidar-enhanced orthophotography processed with a routine to identify topographically low points identifies kariz locations. Study area location is shown in Fig. 3. a A complex of karezes following river systems in alluvial fans radiating off the Hindu Kush in Afghanistan. b Close-up of two sub-parallel karezes. Kariz on the

communication, 2010; Fig. 3). Hydraulic conductivities $\left(K_{\mathrm{h}}\right)$ of the soils were estimated using the Hazen equation $\left(K_{\mathrm{h}}=\mathrm{d}_{10}^{2}\right.$, where $K$ has units of $\mathrm{cm} \mathrm{sec}^{-1}$ and $\mathrm{d}_{10}$ of $\left.\mathrm{mm}\right)$ and converted to $\mathrm{m} \mathrm{day}^{-1}$. The estimated $K_{\mathrm{h}}$ of these samples are consistent with those of sediments behaving as aquifers (Fig. 5a): arithmetic and geometric mean $K_{\mathrm{h}}$ of those soils on alluvial fan material is about 0.8 and $0.004 \mathrm{~m} \mathrm{day}^{-1}$, which is within the range of productive aquifers. $K_{\mathrm{h}}$ determined from pumping test results near Kandahar and in the Kabul Basin (CDM 2003; Fig. 5b) are several orders of magnitude higher, with average $K_{\mathrm{h}} \sim 70 \mathrm{~m} \mathrm{day}^{-1}$. The latter value is similar to an average of the $K_{\mathrm{h}}$ s used by Mack et al. (2010a) for fan alluvium and colluvium $\left(50 \mathrm{~m} \mathrm{day}^{-1}\right)$ and river channel sediments $\left(100 \mathrm{~m} \mathrm{day}^{-1}\right)$ in the Kabul Basin. In alluvial fan sediments, it is expected that finer-grained sediments should be encountered with depth and in distal locations, such that hydraulic conductivity will decrease with depth and distance from the sediment source (Reading 1978; Blair and McPherson 1994); deposition of fluvial sediments on top of alluvial fans could deposit fining upwards sediments on top of the alluvial fan sediments. For the computer simulations of kariz hydraulics in this study, we did not have data to quantify any depth- or spatial-dependence of $K_{\mathrm{h}}$, so we assumed a fairly simple $K_{\mathrm{h}}$ distribution: we assigned the computer model domain a horizontal hydraulic conductivity $\left(K_{\mathrm{xy}}\right)$ of $70 \mathrm{~m} \mathrm{day}^{-1}$ and vertical hydraulic conductivity $\left(K_{\mathrm{v}}\right)$ that is $10 \%$ of $K_{\mathrm{xy}}$.

\section{Kariz dimensions and water discharge rates}

Kariz geometries and water supply rates were compiled from a number of published sources of information, including those from Iran, Iraq, Afghanistan and Pakistan. Described

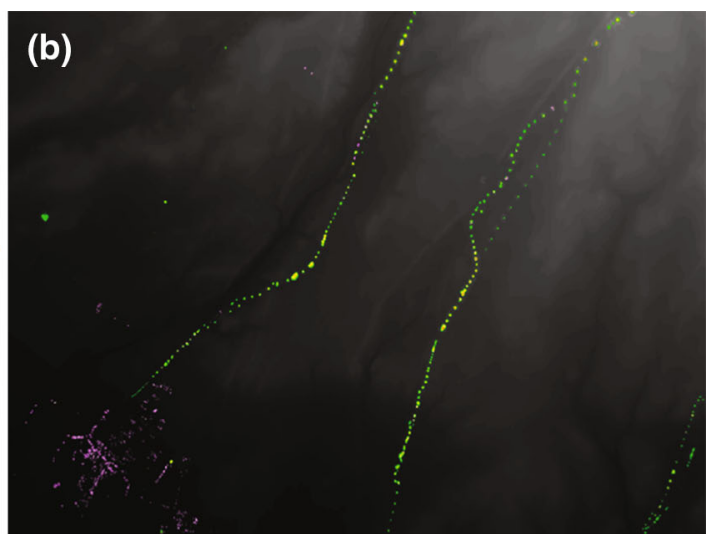

right shows a section (faint green-filled chahs) that appears to be bypassed by newer chahs (bright green-filled chahs). Fuchsia-colored polygons represent positive features detected using first-return from the LiDAR data

below are the ranges of sizes and rates for kariz parameters, with indication of which were selected to represent karezes in the study area for the computer models.

The kariz tunnel is generally $1-2 \mathrm{~m}^{2}$ in cross-section (Beaumont 1973; Lightfoot 2009) and, in Iran, is up to $50 \mathrm{~km}$ long (Beaumont 1989). Most kariz tunnels are less than $5 \mathrm{~km}$ long in Iraq (Beaumont 1989) and closer to $2 \mathrm{~km}$ long in Afghanistan (Banks and Soldal 2002; Rout 2008). The vertical shaft at the topographically highest point is called the sarchah or mother well, and it may be up to $20 \mathrm{~m}$ deep in Afghanistan (Banks and Soldal 2002). In Iran, the modal depth of the sarchah is 10-20 m (Beaumont 1973) and in Iraq the modal depth is $10 \mathrm{~m}$. Other vertical shafts are called chahs and are typically spaced $15-30 \mathrm{~m}$ apart depending upon degree of consolidation of the sediments (Kahlown and Hamilton 1994; Banks and Soldal 2002; Lightfoot 2009). The tunnel is generally linear, although mapped or imaged karezes (Figs. 2, 3, 4) commonly consist of two or more linear segments at slightly different orientations.

The gradient on the horizontal tunnel of the kariz is 1:500-1:1500 (English 1968; Amin et al. 1983; Favre and Kamal 2004) and is less than the gradient of the land surface (Banks and Soldal 2002). Favre and Kamal (2004) have stated that 1:1000 is the maximum gradient: higher gradients result in erosion of the tunnel structure by water flowing in the kariz. Higher gradients can probably be maintained in cemented alluvium, whereas lower gradients are required in unconsolidated materials.

Discharge rates from a kariz to the surface canal vary greatly, depending upon the kariz location and length. A literature survey of reports of kariz flow in Afghanistan, Iran, Pakistan and Saudi Arabia shows that flow rates vary from less than 5 to $500 \mathrm{~L} \mathrm{sec}^{-1}$ (Fig. 6). These data have a 
Fig. 5 Hydraulic conductivity $\left(K_{\mathrm{h}}\right)$ of kariz materials. a $K_{\mathrm{h}}$ estimated using the Hazen equation and $\mathrm{d}_{10}$ of soil samples collected in Afghanistan (J. Kelley, personal communication, 2010; grain size data from Jason McKenna, Julie Kelley, Lillian Wakeley, and Sam Jackson through US Army Engineering Research and Development Center). Almost all are greater than $\sim 9 \times 10^{-5} \mathrm{~m} \mathrm{day}^{-1}$ $\left(10^{-7} \mathrm{~cm} \mathrm{sec}^{-1}\right)$, which is an approximate minimum for aquifers. b Results of pumping tests near Kandahar (white bars; CDM 2003) and in the Logar River alluvial aquifer in the Kabul basin (gray bars; Tünnermeier et al. 2005) presented in order of increasing $K_{\mathrm{h}}$

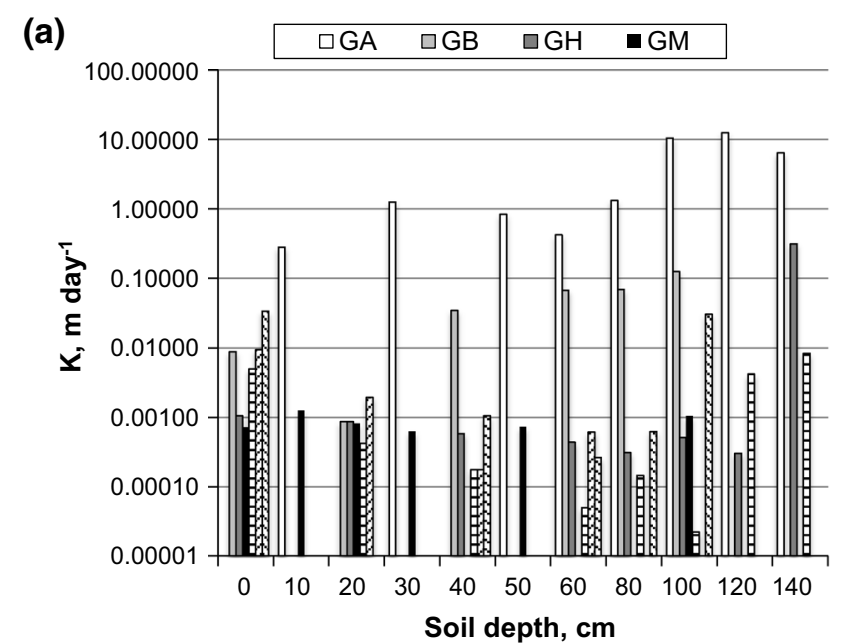

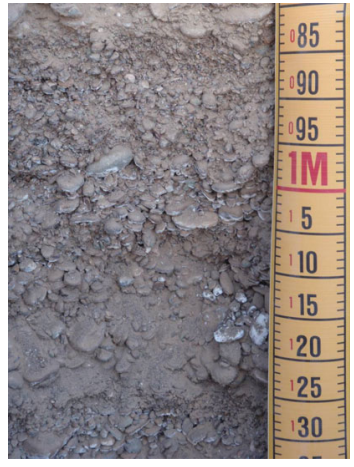

$\mathrm{GH}$ : high gravel content with calcium carbonate pendants.

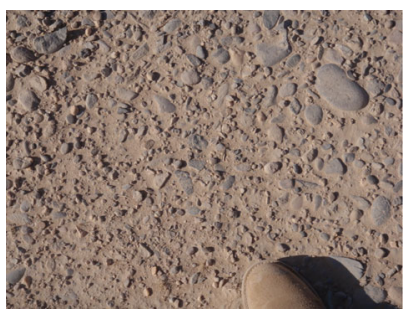

GB: Land surface.

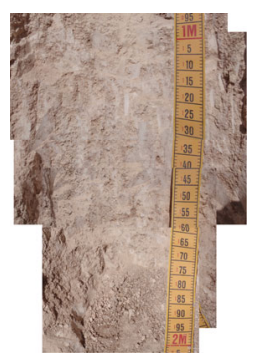

GQ: $100 \mathrm{~cm}$, lowest estimated $\mathrm{K}_{\mathrm{h}}$. (b)

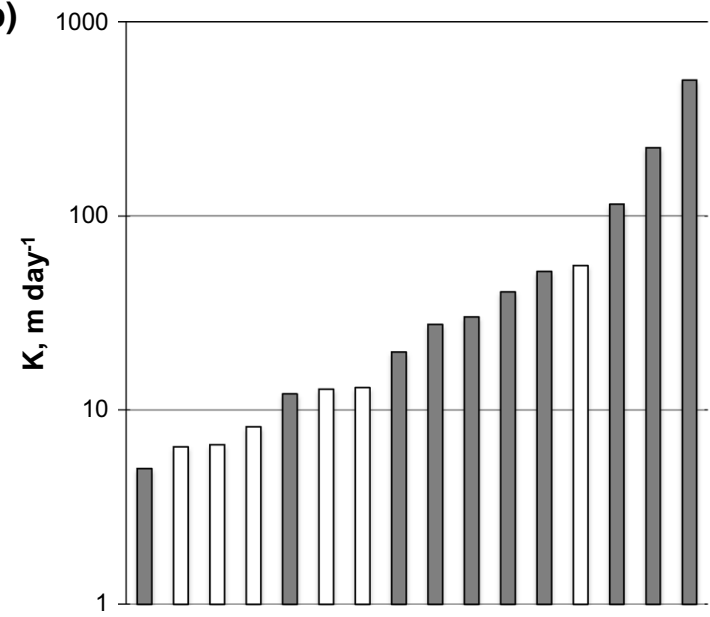

harmonic mean of $13.6 \mathrm{~L} \mathrm{sec}^{-1}\left(\sim 1200 \mathrm{~m}^{3}\right.$ day $^{-1}$ and $\sim 430,000 \mathrm{~m}^{3}$ year $\left.^{-1}\right)$ and a median of $22.4 \mathrm{~L} \mathrm{sec}^{-1}$ $\left(\sim 1900 \mathrm{~m}^{3}\right.$ day $^{-1}$ and $\sim 700,000 \mathrm{~m}^{3}$ year $\left.^{-1}\right)$. These compiled flow rates are broadly similar to flow in qanats in Iran (Beaumont 1989), where measured flow was less than 50 to $\sim 1600 \mathrm{~L} \mathrm{sec}^{-1}$. Flow rate also varies seasonally in many (but not all) karezes, although there has been little quantification of the variability. Kahlown et al. (1988) report that maximum discharge in Baluchistan kariz flow in the Spring season is about $125 \%$ of average lowest flow rate, also similar to variability in Iran qanat flow (Beaumont 1989).

The kariz tunnel near the discharge point (owkura or daylight point) usually lies above the water table, resulting 


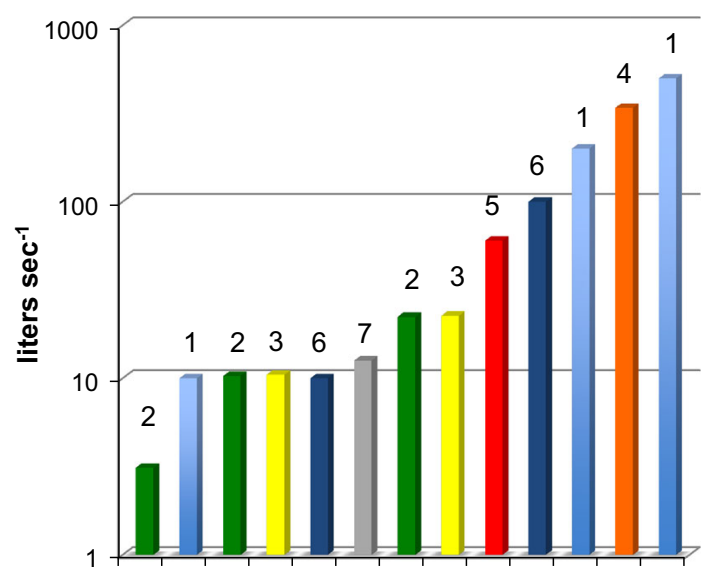

Fig. 6 Literature-reported flow rates in karezes and one well. Sources: 1, Hussain et al. 2008; 2, Kahlown and Hamilton 1994; 3 , Kahlown et al. 1988; 4, McLachlan 1989; 5, Rout 2008; 6, Jentsch 1970; 7, Captain Jubal Grugg, personal communication, 2011, US Army well

in water loss through seepage for some distance along the distal end of the kariz. Kahlown et al. (1988) provided measurements of discharge rates at different locations in the kariz tunnel for several karezes. Decrease in water flow rate is about $22-85 \%$ of the flow measured in the most upgradient part of the kariz. Khan et al. (2015) found that the average conveyance loss in the surface canals fed by karezes near Ghazni was $26 \%$ per kilometer. For this study, we model only the portion of the kariz lying at the water table without consideration of seepage loss within the kariz and surface canal.

\section{Precipitation}

Meteoric precipitation data are scarce in Afghanistan, mostly because of destruction of records and infrastructure during the Soviet occupation of Afghanistan (1979-1989) and the difficulty of reestablishing monitoring stations during subsequent conflicts. Some recent data are available through the US military forces and some historic data are also available; a relatively new climate network operated by Afghanistan (Agromet, http://afghanistan.cr.usgs.gov/ agro) has about 10 years of data that are somewhat complete. Not enough data are available at Kandahar and at stations in the mountains near Kandahar (Fig. 3) to assess annual precipitation trends with much confidence; data presented here are published averages and data from the National Climatic Data Center through the US National Oceanic and Atmospheric Administration (e.g., ftp://ftp. ncdc.noaa.gov/pub/data/inventories/).

Precipitation in Afghanistan is strongly controlled by elevation (FAO 1996; Fig. 7a). At elevations lower than $1000 \mathrm{~m}$, annual precipitation is less than $100 \mathrm{~mm}$ per year and thus the climate is hyperarid, whereas at elevations higher than $5000 \mathrm{~m}$ annual precipitation is greater than $800 \mathrm{~mm}$ per year, and thus slightly higher than precipitation in the semiarid climate category. Only a very small portion of the Hindu Kush receives more than $1000 \mathrm{~mm}$ per year. Some averages reported in the literature, in combination with data from meteorological stations, suggest $\sim 200 \mathrm{~mm} \mathrm{year}^{-1}$ at Kandahar might be a reasonable estimate of annual precipitation, if it can be assumed that data collected in the 1980s are unreliable (Fig. 7b). At Ghazni, about $330 \mathrm{~km}$ northeast of Kandahar, a slightly more consistent temporal record is available. There, average annual precipitation is around $300 \mathrm{~mm}$, but long-term trends are still difficult to interpret from the discontinuous record (Fig. 7c).

Multi-year droughts are frequent in the region (pink shaded years, Fig. 7c). Even 2 years of below-average winter precipitation is thought to result in severe drought (Favre and Kamal 2004). Mountain snow is critical to groundwater recharge and probably more important for understanding the water resource in alluvial fans than annual precipitation amounts in either Kandahar or Ghazni, but quantitative data are scarce. Long-term records of snow cover in Eurasia during the spring show a steady decline since at least 1967 (Fig. 7d).

\section{Groundwater model}

We used Visual MODFLOW (Schlumberger 2009; MODFLOW 2009.1 Pro, build 4.4.0.156, using Modflow v. 1.4.00) to simulate groundwater flow to and water discharge from a kariz in a homogeneous domain. The model parameters were adjusted so that kariz outflow rates are similar to the median of published kariz water flow rates; it is an uncalibrated, unvalidated and generalized model. For simplicity in modeling, we assumed a linear kariz with a gradient of 1:1000. More details are given below in "Results and discussion". The zone budget feature of Visual MODFLOW for the kariz was assumed to represent kariz discharge. For the last model, to more realistically represent removal of water from the kariz to the land surface, the kariz discharge was approximated by placing an artificial well with a fixed discharge rate at the downgradient point at which the kariz elevation is last in contact with the water table.

\section{Population trends in Afghanistan}

Data for trends in population of Afghanistan (Table 2) were compiled from a variety of online sources. No attempt was made to assign credibility levels to these data. Instead, changes in population over time were generally interpreted from all the data. 

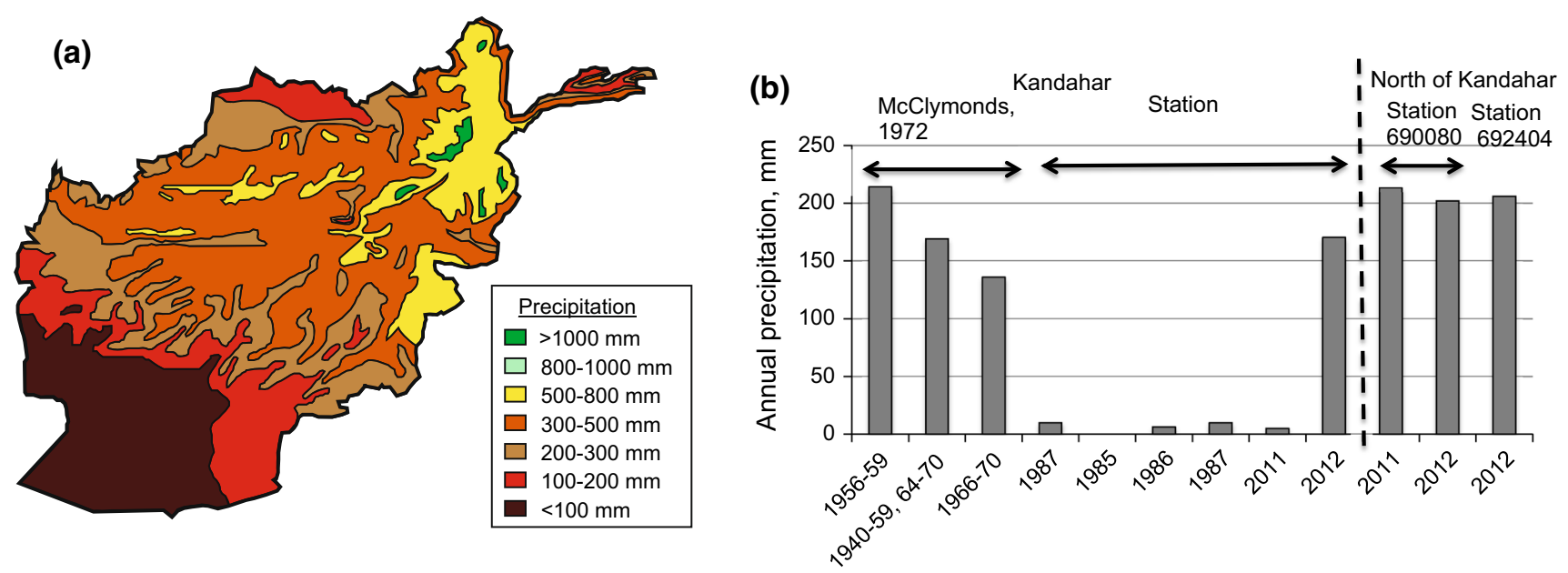

(c)
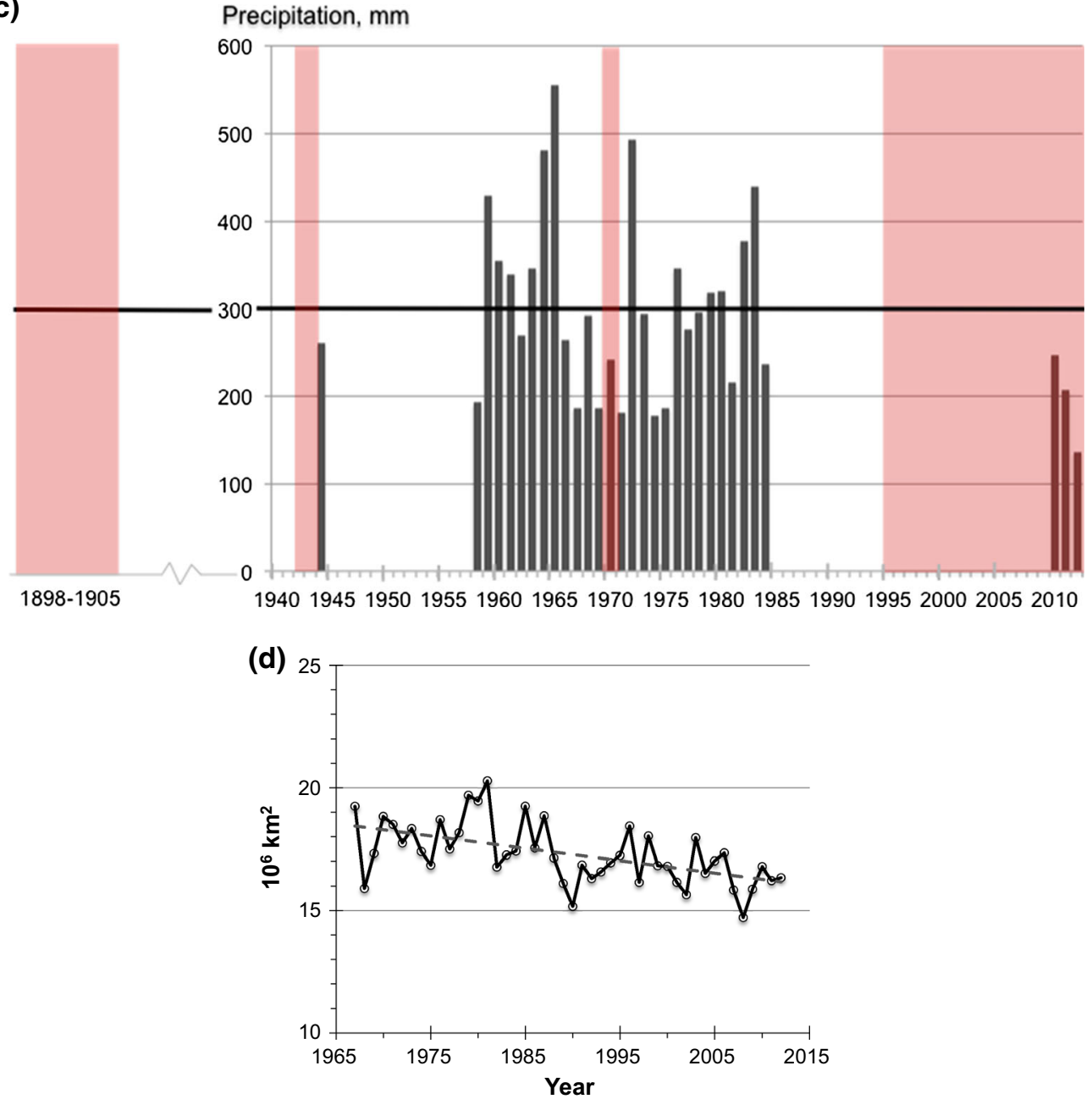

Fig. 7 Meteorological data. a General distribution of precipitation in Afghanistan (modified from Favre and Kamal 2004). b Literature compiled precipitation amounts in Kandahar and nearby monitoring stations in mountains near Kandahar (McClymonds, 1972; NOAA Climate.gov). c Annual total meteoric precipitation in Ghazni, Afghanistan. Data compiled from: NOAA Climatic Data Base Modernization Program, archiving data from these sources: Royal Afghan Meteorological Institute, Royal Government of Afghanistan;
Afghan Air Authority, Civil Aviation and Meteorology, Meteorological Department; and Republic of Afghanistan, Civil Aviation and Tourism Authority, Meteorological Institute. Drought periods shaded in red; mean annual precipitation shown as yellow line. d Average extent of snow cover for March-May in Eurasia, data from Rutgers University Snow Lab (http://climate.rutgers.edu/snowcover/chart seasonal.php?ui_set=eurasia\&ui_season=2; T. Estilow, personal communication, 2013) 
Table 2 Afghanistan population: data sources

\begin{tabular}{ll}
\hline Source \\
\hline 1 & World Resources Institute, 2003, Washington DC, EarthTrends: The Environmental Information Portal (http://earthtrends.wri.org) \\
2 & CIA World Factbook, 2011, (http://www.indexmundi.com/g/g.aspx?c=af) \\
3 & CIA World Factbook, 2012, updated weekly (https://www.cia.gov/library/publications/the-world-factbook/geos/af.html) \\
4 & Encyclopedia of the Nations (http://www.nationsencyclopedia.com/Asia-and-Oceania/Afghanistan-POPULATION.html\#b) \\
5 & United Nations Statistics Division (UNSD) of the Department of Economic and Social Affairs, United Nations Country Profile (http://data.un. \\
& org/CountryProfile.aspx) \\
6 & Encyclopaedia Iranica, 2013, vol. V, Fasc. 2, p. 152-159 (http://www.iranicaonline.org/articles/census-ii) \\
7 & E-Government, Islamic Republic of Afghanistan, cso.gov.af/Content/files/Kandahar(1).pdf, Estimated Population of Afghanistan, 2012-2013 \\
8 & World Food Programme, www.foodsecurityatlas.org/afg/country/provincial-Profile/Kandahar \\
\hline
\end{tabular}

\section{Results and discussion}

In southern Afghanistan, most of the karezes are located sub-parallel to stream channels (Figs. 2, 3b, 4). This suggests that recharge to the alluvial aquifers that host the karezes is dominantly from influent streams and rivers carrying snowmelt from the Hindu Kush (Uhl and Tahiri 2003; Tünnermeier et al. 2005). The models presented here do not consider a river's contribution to recharge, but instead examine water delivery to a hypothetical kariz with constant-head boundaries both up- and downgradient.

To understand how a kariz functions to deliver water, model sensitivity to a variety of model-input factors is first discussed. Then, because water availability in the alluvial aquifers hosting the karezes depends upon recharge, longterm trends in precipitation are shown, especially snowfall in the Hindu Kush, and estimates of changes in aquifer recharge are attempted. Finally, because water use also affects aquifer sustainability, population-growth trends in a representative region are shown, and the potential water use stemming from that population growth along with the potential impacts to kariz discharge rates is considered.

\section{Modeling}

\section{Introduction}

The typical model (Fig. 8) domains, 1000-2000 $\mathrm{m} \times$ 50-1000 m $\times 50 \mathrm{~m}(\mathrm{x}, \mathrm{y}, \mathrm{z})$ were discretized to $10 \mathrm{~m}-$ $20 \mathrm{~m} \times 10 \mathrm{~m}-20 \mathrm{~m} \times 1 \mathrm{~m}$ cells, except for the region representing the kariz. Some special cases of different model domains are described below. The simulated kariz was discretized to $10-20 \mathrm{~m} \times 1-2 \mathrm{~m} \times 0.25 \mathrm{~m}$ cells, corresponding to a cross-sectional area of $1 \mathrm{~m}^{2}$ or $1 \mathrm{~m} \times 2 \mathrm{~m}(\mathrm{x}, \mathrm{z})$. In the different simulations, the kariz length ranged from 0.5 to $1 \mathrm{~km}$. The kariz was centered in the modeling domain, with model boundaries typically $30-100$ and $200 \mathrm{~m}$ from kariz ends for 1000- and 2000-kmlong domains, respectively. Gradient on the simulated kariz tunnel and the water table was generally 1:1000, except during the tests on effects of the gradient and contact length of kariz with water table on kariz discharge. The kariztunnel hydraulic conductivity $\left(K_{\mathrm{k}}\right)$ was simulated by imposing $K_{\mathrm{k}}$ equal to various orders of magnitude greater than that of $K_{\mathrm{x}, \mathrm{y}}$. For $K_{\mathrm{k}} / K_{\mathrm{x}, \mathrm{y}}$ from $10^{7}$ up to $10^{14}$, no significant difference exists in the kariz flow; for ratios larger than $10^{14}$, the model did not converge. For $K_{\mathrm{k}} / K_{\mathrm{x}, \mathrm{y}}$ less than $10^{7}$, the kariz flow was a function of the ratio of the conductivity ratio. We chose to use $10^{7}$, the lowest $K_{\mathrm{k}} / K_{\mathrm{x}, \mathrm{y}}$, to simulate essentially open flow in the kariz tunnel while reducing the calculation time and the possibility of nonconvergence.

Model boundaries for this first set of simulations employed fixed head at the upgradient and downgradient ends of the domain, no flow at the sides and bottom of the domain, and water table at the upper boundary. The fixedhead boundary option strongly affects the model outcome, especially when the kariz termination is near the boundary, so domains were constructed to position the kariz far (100 $\mathrm{m}$ or more) from the upgradient and downgradient boundaries. A single case of a very large domain $(10,000 \mathrm{~m} \times 4000 \mathrm{~m} \times 60 \mathrm{~m})$ with a coarser discretization was used to confirm that boundary proximity in other models was not distorting the model outcome.

Although most conceptual drawings of karezes place the portion of the sub-horizontal tunnel near the sarchah below the water table, it is more likely that the kariz draws down the water table near the sarchah (Beaumont 1973), and that for most of its length the kariz is at the water table (Fig. 1). Groundwater modeling, described in more detail below, supports this conceptual view of a kariz.

For groundwater modeling, we varied the size of the model domain, the kariz-tunnel slope, the water-table slope, and hydraulic conductivity with the goal of simulating kariz discharge on the order of $1200-1900 \mathrm{~m}^{3}$ day $^{-1}$, which is equivalent to the harmonic mean and median kariz flow rates of 14 and $22 \mathrm{~L} \mathrm{sec}^{-1}$. For purposes of modeling, we considered only the portion of the kariz tunnel that was at or 
Fig. 8 Cross-section of typical model domain with boundaries. Zone of high hydraulic conductivity represents kariz. Pumping well, in some simulations, represents delivery of kariz water to land surface (see text)

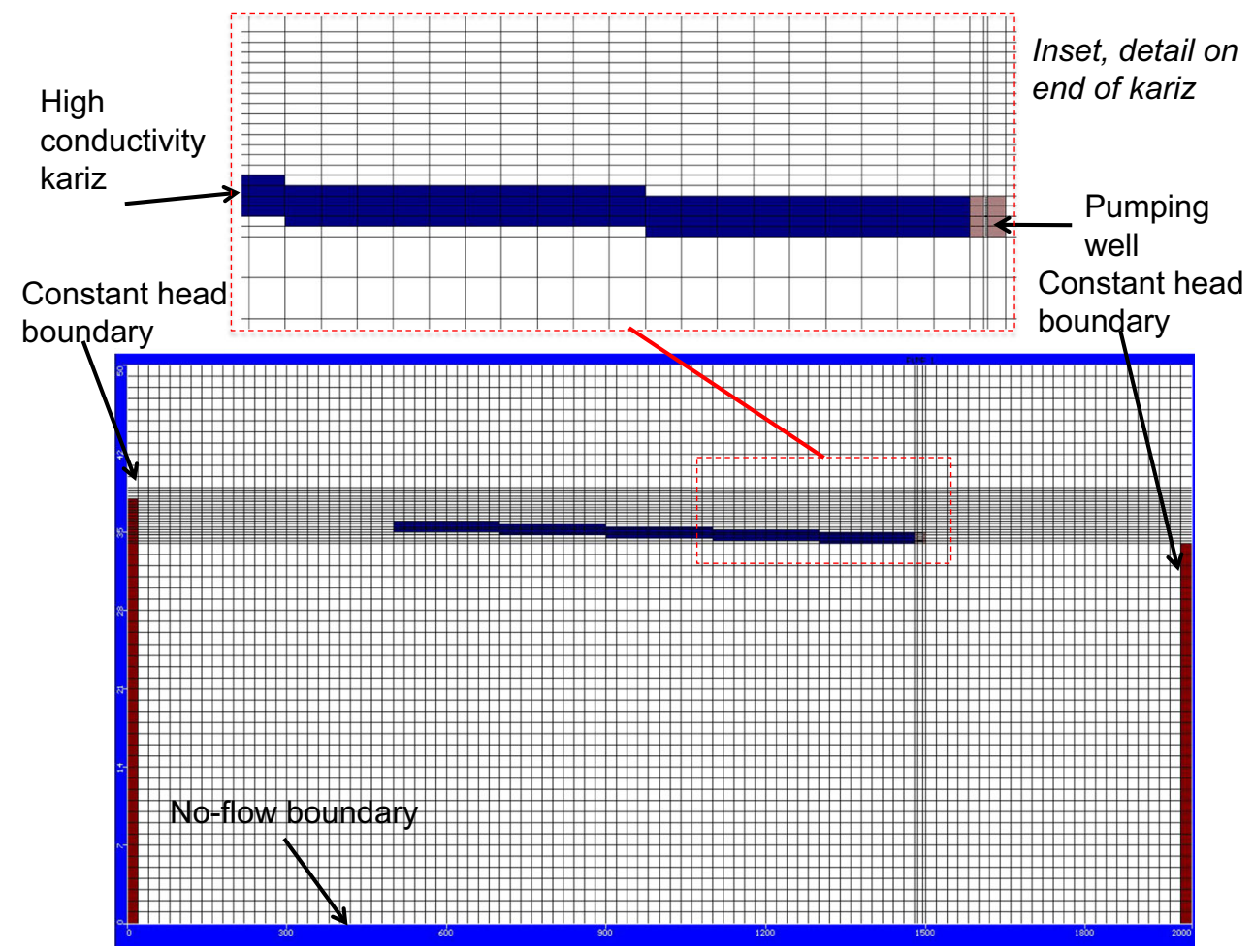

below the water table as a first approximation. Yousefirad et al. (2012) used statistics to show that qanat discharge in central Iran was most strongly related to hydraulic conductivity and storativity of aquifer materials, and secondarily related to kariz gradient and depth to water.

\section{Effect of water-table slope, water-table contact with kariz, and model dimensions}

The slope of the water table and the position of the kariz tunnel with respect to the water table determine the flow rate and the length of the kariz tunnel that contains water: when the kariz is entirely above the water table, no flow occurs, and when the water table is higher than the base of the kariz at the sarchah (chah most proximal to the mountain, Fig. 1), the entire length of the kariz tunnel is wet and the maximum water discharge occurs. Simulations were done for water-table gradients of 0.2-1.5 (Fig. 9a). The results show an approximately linear response of kariz discharge to water-table gradient, so long as the entire length of the kariz is in contact with the water table. The kariz discharge rate increases by a factor of about 2-5 for a doubling of the water-table gradient. However, discharge rate depends strongly on model domain dimensions.

Model width, length, and depth and kariz cross-sectional area all affect the modeled kariz discharge rate (Fig. 9a). The sensitivity to model domain width is much less for large domains (Fig. 9b), with kariz discharge only about $10 \%$ higher for domain widths larger than $500 \mathrm{~m}$ than in those with a domain width of $500 \mathrm{~m}$. Model length must be large enough that the potentiometric contours that are altered by the high hydraulic conductivity kariz do not extend to the model boundaries. For our simulations, this was best accomplished with model domains representing a length at least $2 \mathrm{~km}$ for a domain-centered kariz with a length of $1 \mathrm{~km}$. The effect of model depth (Fig. 9c) is substantial for depths less than about $50 \mathrm{~m}$. For depths of $50 \mathrm{~m}$ and greater, the effect is much smaller than other effects: even though kariz discharge increases with model depth, for a depth increase of $110 \mathrm{~m}$, the kariz discharge increases by only about $13 \%$.

Further investigation of the water-table gradient effect shows the relation of kariz flow rate to the length of the kariz in contact with the water table. Because the watertable height and slope decrease from spring through winter, thus changing the water-table gradient, the length of the kariz, with fixed gradient, in contact with the water table will also change. For a kariz gradient of 1.5 , we found that when the kariz length is not fully in contact with the water table (water-table gradients less than 1.5), the kariz discharge rate increases approximately exponentially (Fig. 9d). When the kariz length is fully in contact with the water table (water-table gradients 1.5 or greater), the discharge rate increases with increasing hydraulic gradient, as discussed above (Fig. 9c).

These results generally support observations that kariz discharge rates are greatest in the spring and early summer after melting of winter snow and subsequent recharge of

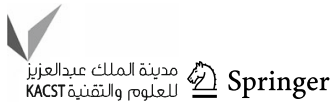




\section{(a)}

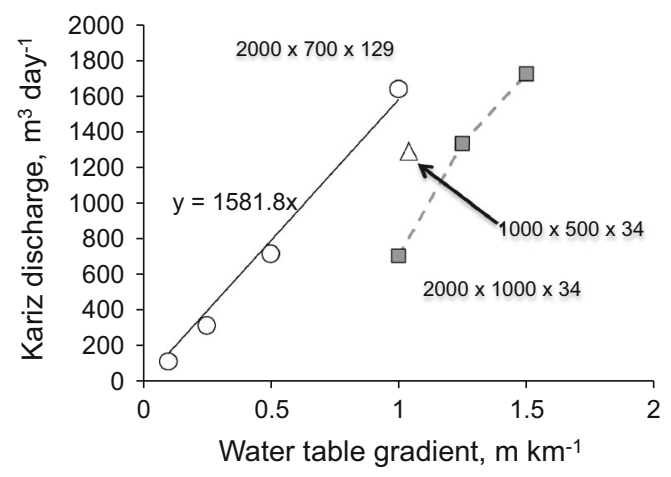

(c)

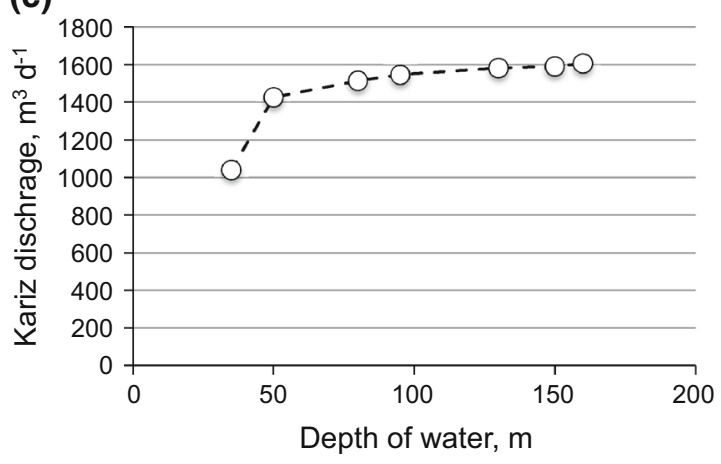

Fig. 9 Gradient and domain size effect on modeling results. a Effect of water-table gradient and domain size on kariz discharge rate. Circles, squares and triangle are models with different domain sizes, as indicated in the figure $(\mathrm{x} \times \mathrm{y} \times$ water depth on downgradient end of model, $\mathrm{m}$; kariz length, $\mathrm{m} \times$ kariz cross-section, $\mathrm{m}^{2}$ ). $\mathbf{b}$ Effect of domain width only on kariz discharge. Domain 2000 m long, $100 \mathrm{~m}$

alluvial fan aquifers, and lower in the autumn and winter seasons (Beaumont 1989).

\section{Effect of hydraulic conductivity of model domain on kariz} discharge

For this initial investigation of the hydrogeology of karezes, we fixed the water-table and kariz gradients to be 1:1000 (m:m), and assumed hydraulic conductivity homogeneity in the horizontal plane $\left(K_{\mathrm{xy}}\right)$, with vertical hydraulic conductivity $10 \%$ of the horizontal value. As described above, the apparent hydraulic conductivity of the kariz $\left(K_{\mathrm{k}}\right)$ is simulated as $10^{7}$ times the $K_{\mathrm{xy}}$. When the conductivity ratio, $K_{\mathrm{k}} / K_{\mathrm{xy}}$, was less than $10^{7}$, the modeled kariz discharge rate decreased non-linearly with decreasing $K_{\mathrm{k}} / K_{\mathrm{xy}}$, but was approximately constant for each $K_{\mathrm{xy}}$ when $K_{\mathrm{k}} / K_{\mathrm{xy}}$ was $10^{7}$ to about $10^{12}$ (Fig. 10a). However, the kariz discharge rate is very sensitive to different $K_{\mathrm{xy}}$ (b)

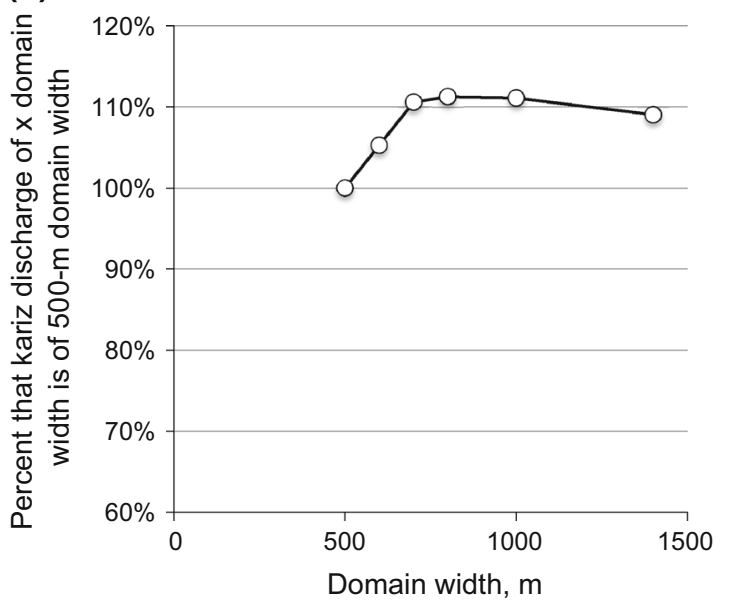

(d)

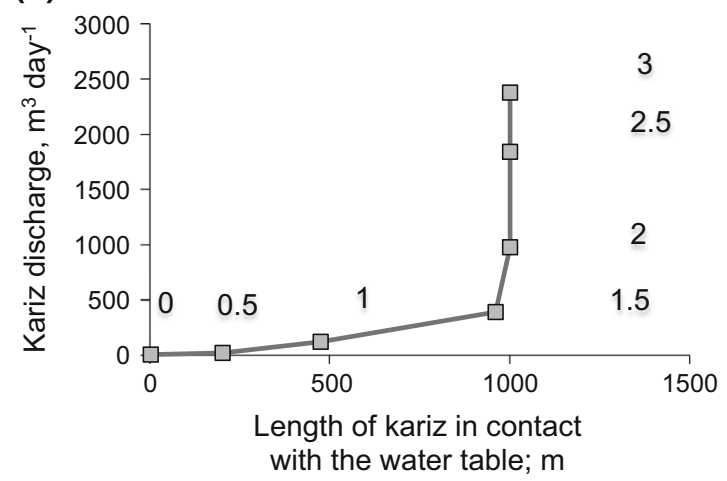

deep. $\mathbf{c}$ Effect of domain depth only on kariz discharge. Domain size $2000 \mathrm{~m} \times 1000 \mathrm{~m} \times 50-160 \mathrm{~m}$ deep; water-table gradient $1 \mathrm{~m} \mathrm{~km}^{-2}$. d Effect of the length of the kariz in contact with the water table on kariz discharge rate. Domain $2000 \mathrm{~m} \times 1000 \mathrm{~m} \times$ $50 \mathrm{~m}$ water depth, kariz $1000 \mathrm{~m} \times 1 \mathrm{~m}^{2}$. Numbers near data points are the water-table gradients in the simulation

(Fig. 10a). For conditions of $K_{\mathrm{k}} / K_{\mathrm{xy}}$ of $10^{7}$ to about $10^{12}$, kariz discharge rates are a linear function of $K_{x y}$ (Fig. 10b). The least-squares linear fit shows that kariz discharge $\left(\mathrm{m}^{3}\right.$ day $\left.^{-1}\right)$ is approximately 25 times the $\mathrm{K}_{\mathrm{xy}}\left(\mathrm{m} \mathrm{day}^{-1}\right)$ when the conductivity ratio is large.

\section{Simulation with kariz discharge removed from model}

Oosterbaan (1982) showed a large-scale, generalized representation of water flow in an alluvial fan. For modeling simplicity and because mapped karezes are many kilometers from the Hindu Kush mountain ridges (Fig. 3), our models represent the region where flow is primarily horizontal (Fig. 11a). Even so, the mass balance requirement of computer models limits the applicability of the models described here to represent kariz discharge: in reality kariz discharge occurs at owkura, the outlet at the land surface, as well as through seepage loss where the kariz lies above 


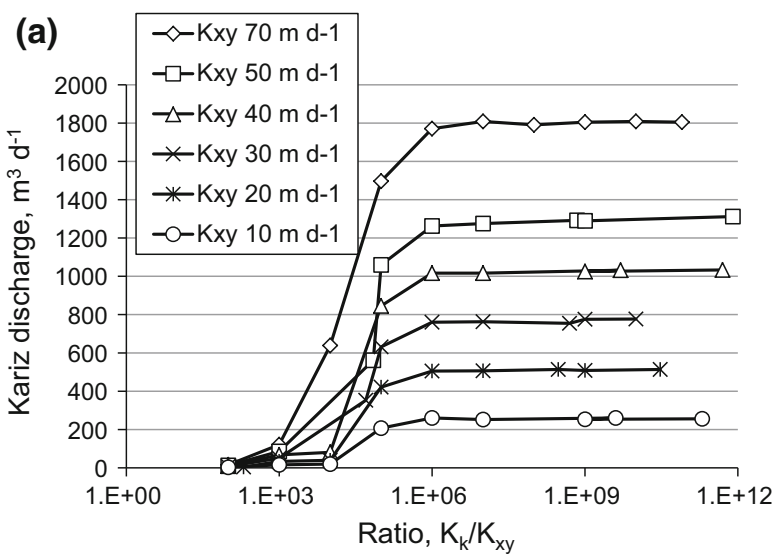

(b)

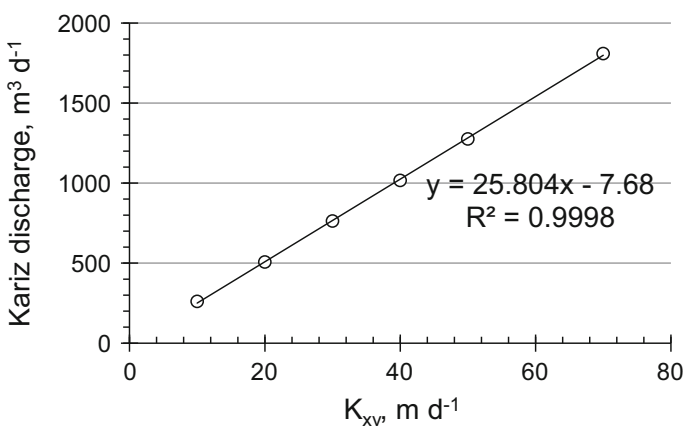

Fig. 10 Hydraulic conductivity and kariz discharge. Model domain $2000 \mathrm{~m} \times 1000 \mathrm{~m} \times 50 \mathrm{~m}$ deep. Kariz $1000 \mathrm{~m} \times 1 \mathrm{~m}^{2}$. a Effect of horizontal hydraulic conductivity and the ratio of kariz hydraulic

conductivity to aquifer hydraulic conductivity on kariz discharge. b Effect of horizontal hydraulic conductivity on kariz discharge. Model domain $1000 \mathrm{~m} \times 500 \mathrm{~m} \times 50 \mathrm{~m}$ deep. Kariz $840 \mathrm{~m} \times 2 \mathrm{~m}^{2}$

the water table; the former process removes water from the aquifer. In the models above, the kariz gained water in its upgradient half, and lost water in its downgradient half, to satisfy mass balance, and the constant-head boundaries dictated the flow field and allowed an infinite amount of water to enter the modeled region. Both a pumping well at the end of the kariz and the DRAIN module of MODFLOW were used to simulate removal of water from the kariz. Results from these simulations are described next.

The pumping well simulated water removal at a point (cell), imitating the owkura, by pumping at the rate similar to the median kariz flow rate, $1900 \mathrm{~m}^{3} \mathrm{day}^{-1}$. The results of this simulation (Fig. 11b) show nearly horizontal flow lines in regions that are upgradient and downgradient of the kariz and pumping well, and strong upward flow to the lower section of the kariz and the pumping well. The constant-head gradient across the model used in this simulation was only 0.5 , much lower than expected for a typical kariz. For this reason, the conservative multiplier for estimating kariz discharge (doubling the discharge when doubling the kariz gradient; "Effect of water-table slope, water-table contact with kariz, and model dimensions") was used to adjust the discharge as calculated by the zone budget. With this adjustment, when the pumping well removed $1900 \mathrm{~m}^{3}$ day $^{-1}$ (prescribed), the kariz discharge was about $1860 \mathrm{~m}^{3}$ day $^{-1}$, very close to the target amount.

The MODFLOW DRAIN module was tested as an alternative method of simulating water removal from the kariz. The DRAIN was assigned to allow the entire length of the kariz, the region previous designated as having $K_{\mathrm{k}} /$ $K_{\text {xy }}$ equal to $10^{7}$, as a drain removing water from the model. The conductance variable for the drain was set at $20 \mathrm{~m}^{2}$ day $^{-1}$. The flow lines show water entering the drain along its entire length (Fig. 11c), similar to what occurs in

the field, but the implication is that water is also leaving the model through the drain along its entire length, which is not what is occurring in the field, although numerically this is not an issue. The drain output, adjusted to a 50-m-deep saturated zone for comparison with other models, was about $1650 \mathrm{~m}^{3} \mathrm{day}^{-1}$, within the desired range of 1200-1900 $\mathrm{m}^{3}$ day $^{-1}$ for the median kariz discharge rate (discussed above). The sensitivity of the drain output to conductance was not tested, but may provide a way to increase flow to the drain.

\section{Summary of model sensitivity simulations}

The computed discharge from a kariz is sensitive to model dimensions, kariz placement within the model, domain hydraulic conductivity, and water-table and kariz gradients. Our tests suggest that $K_{\mathrm{k}} / K_{\mathrm{xy}}$ is optimum at $10^{7}$, and the model domain with little flowline deviation near the model boundaries is $2000 \mathrm{~m} \times 1000 \mathrm{~m} \times 50-150 \mathrm{~m}$. The model depth has small influence on computed kariz discharge once the water depth is $50 \mathrm{~m}$ or greater, with kariz discharge increasing by $13 \%$ when the water depth increased by $110 \mathrm{~m}(50-160 \mathrm{~m})$. The kariz location should be at least $100 \mathrm{~m}$ from all model boundaries. The domain hydraulic conductivity strongly influences kariz discharge, with discharge $\left(\mathrm{m}^{3}\right.$ day $\left.^{-1}\right)$ equal to about 25 times the $K_{\mathrm{xy}}$ $\left(\mathrm{m} \mathrm{day}{ }^{-1}\right)$. Kariz discharge approximately doubles for a doubling of the water-table gradient, although this factor increases for larger domains. Kariz discharge is an exponential function of the length of the kariz in contact with the water table, until the entire kariz length is in contact with the water table. A pumping well positioned at the kariz end successfully simulates removal of water from the model in the same way that water is discharged from the end of a kariz. Use of the DRAIN module is partially

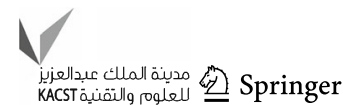


(a)

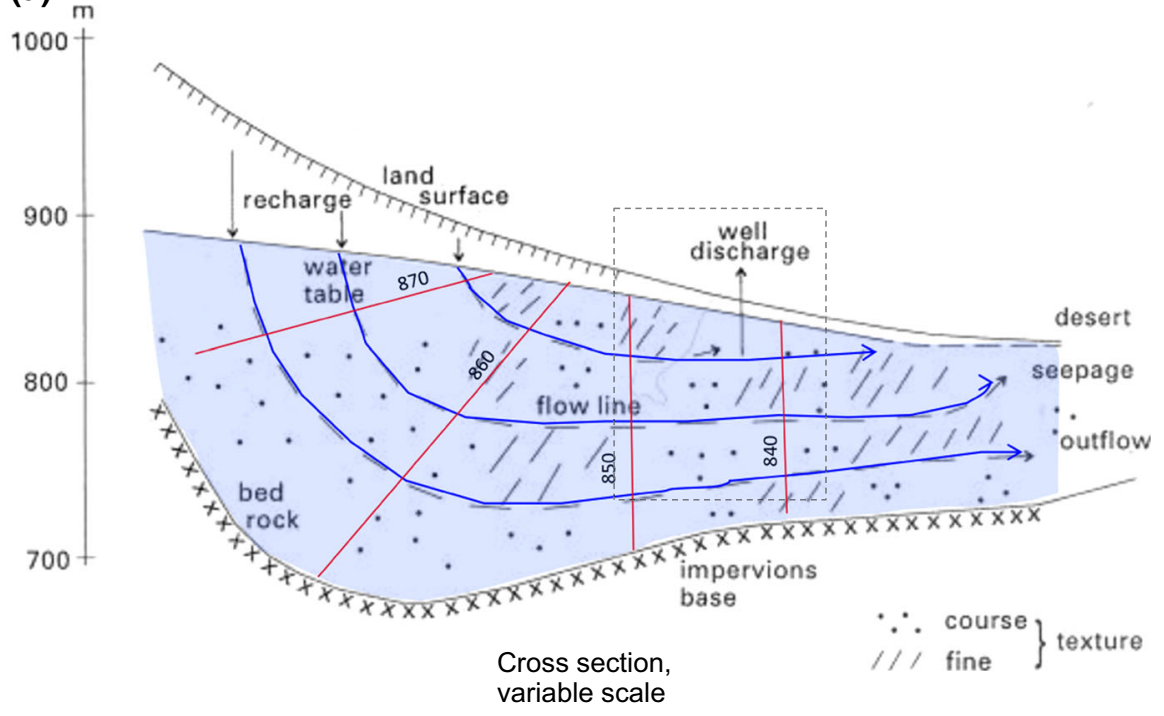

(b)

Pumping well

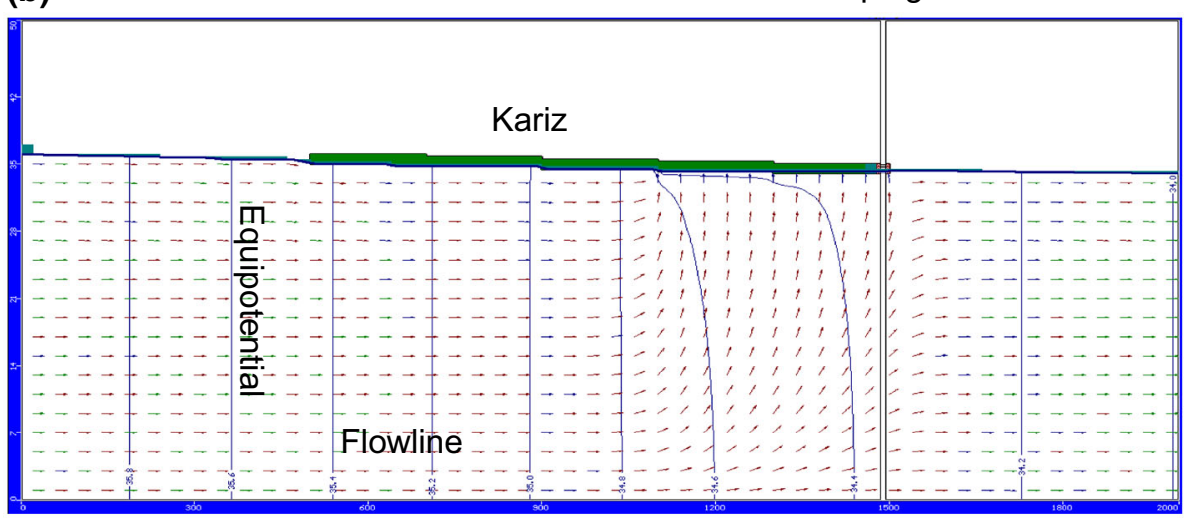

(c)

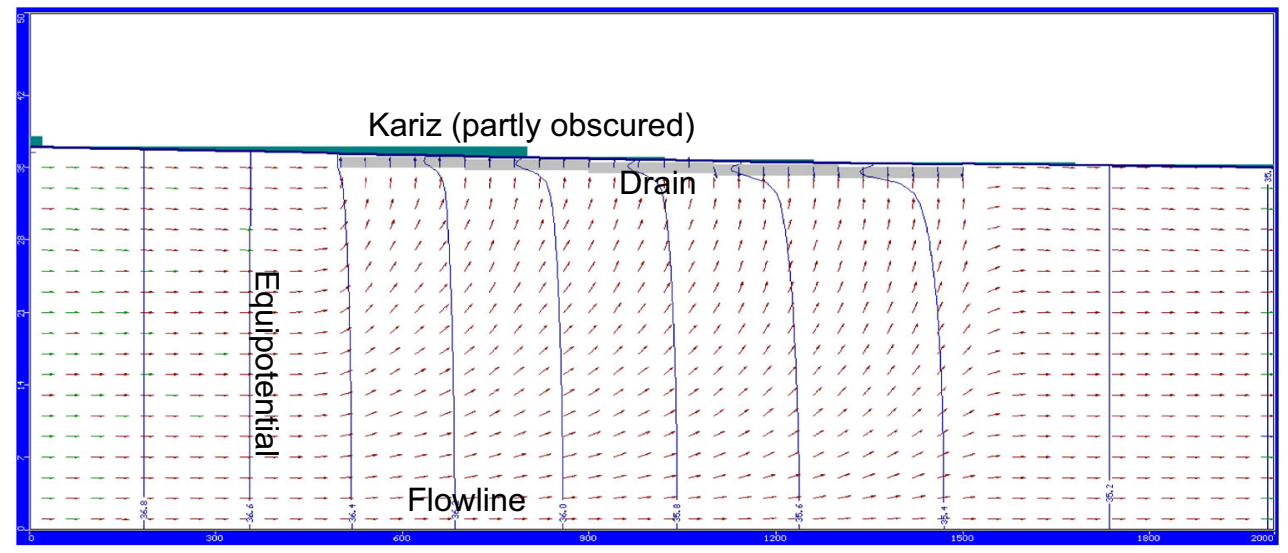

Fig. 11 Model concept and selected results. a General location of computer simulations in this study (dashed box), placed where flowlines are approximately horizontal, in a theoretical broad alluvial fan aquifer flanking the Hindu Kush (modified, from Oosterbaan 1982). Red, equipotential lines; blue, flow lines. b Cross-section of model results for a pumping well $\left(1900 \mathrm{~m}^{3}\right.$ day $\left.^{-1}\right)$ simulating kariz discharge removing water from the alluvial fan aquifer. Model domain $2000 \mathrm{~m} \times 1000 \mathrm{~m} \times 50 \mathrm{~m}$ deep; kariz $1000 \mathrm{~m} \times 1 \mathrm{~m}^{2}$ water-table gradient 0.5 . c Using the "DRAIN" module in MODFLOW (gray sub-horizontal bar) results in water removal along the entire length of the kariz, which is not realistic. Model domain $2000 \mathrm{~m} \times 1000 \mathrm{~m} \times 50 \mathrm{~m}$ deep; kariz $1000 \mathrm{~m} \times 1 \mathrm{~m}^{2}$, water-table gradient 1.0 
successful in the drain output approaches the $22 \mathrm{~L} \mathrm{sec}^{-1}$ median kariz flow rate, but is unrealistic in that it removes water from the model over the entire $1 \mathrm{~km}$ length of the drain, rather than just at the lower end.

Preliminary simulations using RECHARGE instead of constant-head boundaries suggest that more than $1000 \mathrm{~mm}$ of annual precipitation is required to result in discharge from a single kariz of $14-22 \mathrm{~L} \mathrm{sec}^{-1}$ in the 1 by $2 \mathrm{~km}$ model area. This is unrealistic, because only in the highest parts of the Hindu Kush are precipitation rates this high, and because multiple karezes usually occupy a single river valley. Influent rivers carrying snowmelt are the probable largest source of recharge to the aquifers supplying karezes (e.g., Banks and Soldal 2002; Houben et al. 2009a, b).

Mechanically-pumped deep-water wells may have a significant effect on the water-table elevation of an alluvial aquifer and, therefore, kariz flow (Shobair and Alim 2004). Banks and Soldal (2002) suggest a minimum distance of $500 \mathrm{~m}$ between pumped wells and karezes, using some basic calculations. Preliminary modeling work for this project suggests the capture zone of a kariz is at least $600 \mathrm{~m}$ wide and $50 \mathrm{~m}$ deep for the target kariz discharge rate and $K_{\mathrm{k}} / K_{\mathrm{xy}}$ of $10^{7}$, but more work is needed to better constrain the capture zone and clarify the factors that influence it the most.

\section{Precipitation, climate, and groundwater recharge}

The political turmoil, sourced both from internal conflicts and invasions by external forces, which has characterized Afghanistan since at least the middle of the last century has made collection, preservation and dissemination of meteorological data extremely difficult. Most available data are relatively recent (Fig. $7 \mathrm{~b}, \mathrm{c}$ ), not long enough to interpret trends. Droughts lasting more than 5 years are frequent (Fig. 7c), the most recent ones (1998-2006, 2008-2009, 2011; Shroder 2014; and possibly 2013-2014) resulting in serious food shortages and documentation of karezes going dry (e.g., Shobair 2002; Shobair and Alim 2004). Even 2-year winter-precipitation droughts are thought to create severe drought conditions (Favre and Kamal 2004), a feature that underscores the vulnerability of this region to water insecurity. In general, annual precipitation in the Kandahar region is on the order of $200 \mathrm{~mm}$ year $^{-1}$, with nearby mountainous regions receiving two to five times more. Re-establishment of meteorological and other types of monitoring stations provides hope for more and better data in the future (Campbell 2015).

Some climate trends have been reported for the larger region. In the Middle East region, for the period of 1950-1990, the average annual air temperature increased linearly at a rate of $0.07{ }^{\circ} \mathrm{C}$ per decade (Nasrallah and Balling 1993). Klein Tank et al. (2006) showed statistically significant decreases in daily minimum temperatures (consistent with long-term trends) and increases in daily maximum temperatures (consistent with multi-decadal variability) from 1961 to 2000 for central and south Asia; changes in precipitation over the region were not statistically significant. IPCC predictions are for temperature increases on the order of $3-5{ }^{\circ} \mathrm{C}$ by the end of this century, although the predictions have a high degree of uncertainty (e.g., Mannig et al. 2013; Hijioka et al. 2014; Fig. 24-2). Shroder (2014) stated predictions for temperature increases of $2-6.2{ }^{\circ} \mathrm{C}$ by the $2090 \mathrm{~s}$, on top of the increase of $0.8-1{ }^{\circ} \mathrm{C}$ over the last half century. In addition, the next half century may bring a decrease in total annual precipitation by $10-15 \%$ in Afghanistan (Vining and Vecchia 2007), and Milly et al. (2005) have suggested a reduction in surface runoff of 20-30\% for Afghanistan. Evapotranspiration is also expected to increase because of the warming (Kakar et al. 2011). The central Asian region remains a challenging area to model precipitation and temperature on any large scale, however (e.g., Schiemann et al. 2008; Mannig et al. 2013), because of paucity of historical and contemporary data and complexity of the climate drivers in the area. A review of much of the literature on waterrelated trends for the mountain ranges just to the east of the Hindu Kush (Unger-Shayesteh et al. 2013) suggests that the projected warming trends are supported, but changes in precipitation are less certain. Nevertheless, warming, especially in combination with reduction in snowfall, will reduce snowpack in the Hindu Kush, leading to reduced groundwater recharge.

Few published estimates of aquifer recharge rates exist for the study area, but the major river systems are better studied. Most karezes in the study area are constructed in alluvial fans; a few may be located in alluvium adjacent to small or, even more rarely, large rivers. Karezes tap groundwater supplied by diffuse recharge and/or by influent rivers, so a brief discussion of river hydrology is relevant. The Upper Helmand River basin was defined by Vining and Vecchea (2007) as the Helmand River drainage above the Kajakai Reservoir and including the Tirin River watershed drainage. They performed a statistically based water-balance model of the river that showed that net precipitation was highest in March, April, and May, corresponding to high discharge rates in the river, and existing water demands were highest in March, June, July, and August. Whitney (2006) studied the Lower Helmand River basin, the upper boundary of which is near the location of the Kajakai Reservoir. River discharges (Helmand and Arghandab) were highest in March through June, although the annual total ratio of precipitation to pan evaporation over the region ranged from 0.016 to 0.08 , emphasizing the semiarid to arid character of the region. For both the Upper and Lower Helmand River basins, snowmelt was the principal source of water in the rivers. 
Estimates of groundwater recharge are few, with little documented methodology for the estimation methods for Afghanistan locations other than the Kabul Basin to the north. Uhl and Tahiri (2003), described in more detail below, and Uhl (2006) as well as several other investigators has used the FAO (1996) recharge estimation method of groundwater recharge being $10 \%$ of average annual meteoric precipitation. Uhl and Tahiri (2003) estimated average annual precipitation to be about $250 \mathrm{~mm}$ in the eastern Helmand River basin, defined to include parts of the Kandahar, Paktya, and Paktika Provinces, and all of the Ghazni and Zabul Provinces. They estimated recharge to the unconsolidated Quaternary and Neogene deposits to be $10 \%$ of precipitation (citing FAO 1996), or about 530 million $(\mathrm{M}) \mathrm{m}^{3}$ year $^{-1}$. Groundwater use at the time of that publication, principally from the Quaternary and Neogene deposit aquifers, was $750 \mathrm{M} \mathrm{m}^{3}$ year $^{-1}$, more than $40 \%$ greater than estimated recharge. However, they also stated that aquifers in which karezes are constructed are recharged by rivers carrying snowmelt from the mountains (Uhl and Tahiri 2003). Houben et al. (2009a) investigated the hydrogeology of the Kabul Basin to the north of our study area. They also estimated the maximum recharge from precipitation to be about $10 \%$ of the precipitation value, but, in addition, stated that known water demand far exceeds this amount and that the deficit must be filled by infiltration of river water carrying snowmelt in the spring season. Tünnermeier et al. (2005) demonstrated that riverbed infiltration is the predominant form of groundwater recharge in the Kabul Basin, and that it constitutes as much as 92, 90 and $71 \%$ of the total recharge in the Logar, Paghman, and Kabul aquifers, respectively.

Afghanistan is similar to other arid and semiarid regions, so it is useful to consider what is known about recharge in other water-stressed areas. Scanlon et al. (2006) assessed a variety of different methods of evaluating recharge rates in semiarid, arid and hyperarid regions of much of the world. The study did not, however, include any sites in Afghanistan. Scanlon et al. (2006) found that, as a group, recharge rates were about $3 \%$ of precipitation rates. In the same study, areas with irrigation showed higher recharge rates, at about $15 \%$ of the sum of precipitation and irrigation loading. The few areas in that study that might have mountain snowmelt recharge similar to Afghanistan also had higher percent recharge rates $(>20 \%)$. Further, a study done principally in Uzbekistan and Tajikistan (Barlow and Tippett 2008) showed a strong link between river discharge rates and the prior winter conditions, including precipitation and moisture transport by jet-level winds. Therefore, it is likely that snowmeltcarrying rivers and winter precipitation are more important metrics of potential groundwater recharge in southern
Afghanistan than local average annual meteoric precipitation.

Because snow and snowmelt are apparently critical to groundwater recharge, an assessment of trends in snow precipitation and snow cover is useful. Historical data are sparse in the region, but evidence exists that snow cover and glaciers are declining, possibly as much as $60 \%$ in surface area in northern Afghanistan (Makhmadaliev et al. 2008). Using satellite data, Haritashya et al. (2009) and Sarikaya et al. (2012) studied the decline in mountain glaciers in eastern Afghanistan, showing that $77 \%$ of glaciers had retreated (1976-2007) with the largest average retreat of $36 \mathrm{~m} \mathrm{year}^{-1}$ (1976-2003). Unger-Shayesteh et al. (2013), reviewing literature about water cycle north and east of Afghanistan, found general agreement and supporting data that both large and small glaciers are shrinking and ice mass balance studies support the loss of ice from glaciers. The long-term, approximately linear decline in spring snow cover in all of Eurasia (Fig. 5d; Robinson et al. 1993; Robinson and Frei 2000; Frei et al. 2012) corroborates these observations: from 1967 through 2012, area covered by snow decreased by about $5 \%$ per year. Along with decreased glacier-covered area is the potential for increased runoff in rivers draining the mountainous areas. Unger-Shayesteh et al. (2013), studying the Pamir and Tien Shan mountain ranges to the east and northeast of Afghanistan, found that river runoff from terrains containing glaciers was increasing, whereas runoff from terrains not containing glaciers was not. Attempts to differentiate the percentage of river runoff contributed by melting of the seasonal snowpack from that by melting of glacier ice have not yet been quantitatively successful, due to a lack of adequate data to enter into a distributed hydrologic model (Unger-Shayesteh et al. 2013).

In summary, estimates of recent water needs exceed river water availability in portion of the Helmand River system that drains the area near Kandahar, used as a type area for kariz modeling in this study. Rising air temperatures are likely causing shrinking of mountain glaciers, with Afghanistan's glaciers showing large retreat. No clear consensus of predictions exists about climate change-driven changes in precipitation amounts or seasonality. The melting of the seasonal snowpack and glacier ice is causing higher river runoff in some areas to the north and east of the study area. It is likely that this increased runoff is temporary and will decrease as glaciers retreat. Increased runoff as a result of the climate-warming trend may have already passed in Afghanistan, considering that a decrease in snow-covered area of up to $60 \%$ has occurred in the Hindu Kush. Because the rivers in the Kabul Basin are known to lose up to more than $90 \%$ of their flow to groundwater recharge, it is reasonable to 
assume that the Helmand River and its tributaries also recharge groundwater effectively. With decreased snow cover resulting in decreased runoff, groundwater recharge in the Helmand River basin is likely to be decreasing substantially, as well.

\section{Population and water use}

The first national population survey of Afghanistan occurred in 1960 as a population sampling rather than a statistical survey (data source 6, Table 2); the first valid census occurred in 1979 (data source 6, Table 2). From 1988 to 2000, no surveys were made because of military invasion and internal conflict. The population of Afghanistan was about $22 \mathrm{M}$ in 2000, according to Shobair and Alim (2004). However, the population of Afghanistan is difficult to quantify because there are both nomadic and semi-nomadic populations (Kuchis), and the nomadic population is approximately $20 \%$ of the total population. Further, reporting and estimation methods have differed over the years; some inhabitants refuse to cooperate, believing such surveys are invasions of privacy; and extreme losses during military conflicts are difficult to count (e.g., Livingston and O'Hanlon 2012). Further, political influence may have also compounded errors. Although data are discontinuous and estimates are likely flawed, it is apparent that the population more than doubled from the 1960s to the 1980s (Table 3). From 2000 to 2008, population increased steadily; in 2009 the population apparently decreased by about $13 \%$. Nevertheless, the overall trend is increasing population. Estimates of average annual growth rates from data sources in Table 2 are variable: $1.3 \%$ (2000-2012, data source 3 ), $2.22 \%$ (2012, data source 3), $2.4 \%$ (2011, data source 2), $2.6 \%$ (1972-1979, data source 6), $3.1 \%$ (2000-2012 and projected to 2015, data source 4), $3.2 \%$ (1960-2012, data source 1) and $3.9 \%$ (2000-2005, data source 5). The average of the longer-than-decadal-data-based annual averages since year 2000 is $2.2 \%$ (data sources 3 and 4, Table 2), which is used in calculations herein.

In Kandahar Province, the area that includes the focus area of this project, population is estimated to be about 0.91-1.1 M, the range coming from different sources of information (data sources 7 and 8, Table 2). To estimate water consumption due to population increase, we first chose the districts in Kandahar Province that would most likely be using water from karezes, based on geology (Doebrich and Wahl 2006; Quaternary alluvium preferred), degree of urbanization (Google Earth; rural areas preferred), and proximity to surface water (Google Earth; proximity not preferred). This resulted in selection of six districts (Arghanhab, Ghorak, Khakrez, Nesh, Shah Wali Kot, Zhari; Fig. 3) with a total 2012 population of about
250,000 (data source 8 , Table 2; all population numbers are rounded to two significant figures). The land area underlain by geologic material suitable for karezes is about $62 \%$ of the total surface area of those districts, or about $5900 \mathrm{~km}^{2}$. Because these are rural districts we also assumed the population deriving water from karezes was $62 \%$ of the total population, which likely results in a conservative estimate of population using groundwater. Using a $2.2 \%$ growth rate to extrapolate backwards in time, the total population in these districts collectively increased from about 190,000 in 2000 to 250,000 in 2012, and the population estimated to be using kariz water increased from 110,000 to 140,000 .

Gleick (1996) set guidelines for minimum amounts of water for domestic water use at $50 \mathrm{~L}_{\text {person }}{ }^{-1}$ day $^{-1}$ $\left(18.3 \mathrm{~m}^{3}\right.$ person $^{-1}$ year $\left.^{-1}\right)$, including drinking, food preparation, bathing and sanitation. Without the allotment for sanitation, the domestic water use is $30 \mathrm{~L}_{\text {person }}{ }^{-1}$ day $^{-1}\left(11.0 \mathrm{~m}^{3}\right.$ person $^{-1}$ year $\left.^{-1}\right)$. In addition, Gleick (1996) suggested a minimum of about $3240 \mathrm{~L}^{-1}$ person $^{-1}$ day $^{-1}\left(1180 \mathrm{~m}^{3}\right.$ person $^{-1}$ year $\left.^{-1}\right)$ in arid regions such as Egypt for food-crop irrigation. The sum of minimum domestic use and food-crop irrigation water, then, is close to $1200 \mathrm{~m}^{3}$ person $^{-1}$ year ${ }^{-1}$, a number that is considered to represent water stress by the United Nations: recommended water allotment is $1700 \mathrm{~m}^{3}$ person ${ }^{-1}$ year $^{-1}$, water stress is $1000-1700 \mathrm{~m}^{3}$ person $^{-1}$ year $^{-1}$, water scarcity is 500-1000 $\mathrm{m}^{3}$ person $^{-1}$ year $^{-1}$, and absolute water scarcity is less than $500 \mathrm{~m}^{3}$ person ${ }^{-1}$ year $^{-1}$ (UN Water 2013). The entire Helmand River Basin can supply water no higher than the water stress category (Kakar et al. 2011).

Daily domestic water use in Afghanistan is most likely lower than Gleick's (1996) recommendation. FHCRAA (2002) reported daily domestic water use in Afghanistan was $27 \mathrm{~L}$ per capita $\left(10 \mathrm{~m}^{3}\right.$ person $^{-1}$ year $\left.^{-1}\right)$. Favre and Kamal (2004) suggested that domestic water use is no more than $9 \mathrm{~m}^{3}$ person $^{-1}$ year $^{-1}$ (25 L person ${ }^{-1}$ day $\left.^{-1}\right)$, calculated from a maximum domestic water use of $200 \mathrm{M} \mathrm{m}^{3}$ year $^{-1}$ and population of $22.2 \mathrm{M}$ (year 2000 population). Kakar et al. (2011) suggested a minimum of $20 \mathrm{~L} \mathrm{person}^{-1}$ day $^{-1}$ $\left(7.3 \mathrm{~m}^{3}\right.$ person $^{-1}$ year $\left.^{-1}\right)$ for domestic use.

Irrigation water use in Afghanistan is approximately 24,000 $\mathrm{M} \mathrm{m}^{3}$ year $^{-1}$ (Favre and Kamal 2004). With the total irrigated area of about $23,850 \mathrm{~km}^{2}$ (Favre and Kamal 2004), irrigation water use is on the order of $1 \mathrm{M} \mathrm{m}^{3} \mathrm{~km}^{-2} \mathrm{year}^{-1}$, which is $10,000 \mathrm{~m}^{3} \mathrm{ha}^{-1}$ year $^{-1}$ or about $1000 \mathrm{~m}^{3}$ person $^{-1}$ year $^{-1}$ (using year 2000 population). In Kandahar Province, $63 \%$ of the irrigation systems use groundwater directly, either from springs, wells, or karezes (FHCRAA 2002). These water systems irrigate approximately 5000, 1500 , and 15,000 hectares (ha), respectively, in Kandahar Province; the median irrigated farm size in Afghanistan is 1.4 ha and farms smaller than 0.5 ha are considered to be too 
Table 3 Afghanistan population: estimates of Afghanistan population over time

\begin{tabular}{|c|c|c|c|c|c|}
\hline Data sources ${ }^{\mathrm{a}}$ & 1 & 2 & 3 & 4 & 5 \\
\hline 1960 & $11,000,000$ & & & & $11,000,000$ \\
\hline 1979 & $14,000,000$ & & & & $14,000,000$ \\
\hline 2000 & $22,000,000$ & $26,000,000$ & & & \\
\hline 2001 & & $27,000,000$ & & & \\
\hline 2002 & & $28,000,000$ & & & \\
\hline 2003 & & $29,000,000$ & & $24,000,000$ & \\
\hline 2004 & & $29,000,000$ & & & \\
\hline 2005 & & $30,000,000$ & & & \\
\hline 2006 & & $31,000,000$ & & & \\
\hline 2007 & & $32,000,000$ & & & \\
\hline 2008 & & $33,000,000$ & & & \\
\hline 2009 & & $28,000,000$ & & & \\
\hline 2010 & & $29,000,000$ & & & $31,000,000$ \\
\hline 2011 & & $30,000,000$ & & & \\
\hline 2012 & $30,000,000$ & $30,000,000$ & & & \\
\hline 2013 & & & $31,000,000$ & & \\
\hline \multicolumn{6}{|l|}{2014} \\
\hline 2015 & & & & $35,000,000$ & \\
\hline
\end{tabular}

${ }^{a}$ Numbers refer to numbered sources listed in Table 2; all values are rounded to two significant figures

small to provide a living for a family through crop production (FHCRAA 2002). Using the irrigation rate of $10,000 \mathrm{~m}^{3}$ $\mathrm{ha}^{-1}$ year $^{-1}$, the median kariz-supplied farm requires $14,000 \mathrm{~m}^{3} \mathrm{ha}^{-1}$ year $^{-1}$. The kariz flow rate range used in computer modeling above, 14-22 $\mathrm{L} \mathrm{sec}^{-1}$, is equivalent to about 430,000-700,000 $\mathrm{m}^{3}$ year $^{-1}$, and thus could supply nearly 30-50 farms that are 1.4 ha in area.

The sum of estimated domestic water use in Afghanistan (20-27 $\mathrm{L} \mathrm{person}^{-1} \mathrm{day}^{-1}$, or 7.3-10 $\mathrm{m}^{3}$ person $^{-1}$ year $^{-1}$ ) plus irrigation water use $\left(1100 \mathrm{~m}^{3}\right.$ person $^{-1}$ year $\left.^{-1}\right)$ is slightly less than Gleick (1996) suggested for arid region water use, and within the UN category of water stress but approaching the category of water scarcity.

Because increasing population will result in increased water consumption, the impact on groundwater storage can be estimated. In this calculation, all water use is considered consumptive use, even though some water may return to aquifers through infiltration during over-irrigation, especially considering Afghani farmers may still be using traditional irrigation methods (FHCRAA 2002). Even if some irrigation water is returned to aquifers, it is returned downgradient of the portion of the aquifer delivering water to a kariz, and so it will not raise water levels in the capture zone of a kariz. So, using the water use levels defining the upper and lower boundaries of the water stress category, and setting the annual population-growth rate at $2.2 \%$, water use in the districts of Kandahar Province that likely mostly use primarily kariz-produced water increased by about $30 \%$ from 2000 to 2012 (Fig. 12a).
The impact of human use of water on aquifer water levels and kariz water production can be evaluated in a relative sense, assuming the water consumption in 2000 represents a level of use that was recharged that year and was sustainable (not resulting in long-term decline of the groundwater resource). The population growth and consequent increased water use by that increased population, using the time period from 2000 to 2012, was about $1.5-2.5 \mathrm{~km}^{3}$ above sustainable level (water scarcity and water stress levels of water consumption), for the identified districts used as an example in this exercise. Using the $5945 \mathrm{~km}^{2}$ area in the six districts identified above that appear to likely use kariz-produced water, and a porosity of $7.5 \%$ (Tunnermeier et al. 2005) to $30 \%$ (estimated maximum for unconsolidated coarse-grained basin fill), the water-level decline caused by that much water withdrawal is $0.84 \mathrm{~m}$ (highest porosity and lowest estimated water use) to $5.6 \mathrm{~m}$ (lowest porosity and highest estimated water use). Therefore, because the typical kariz gradient is $1 \mathrm{~m} \mathrm{~km}^{-1}$ and kariz length averages about $1 \mathrm{~km}$, even the highest porosity and smallest estimated amount of water use from 2000 to 2012 would cause the water table such that only about $15 \%$ of the kariz would be able to receive water from the water table. This would greatly reduce water production from the kariz. Conditions of lower porosities and either water stress or water scarcity levels of water use would all cause the kariz to stop water production, because the water table would drop below the elevation of the kariz. 
(a)

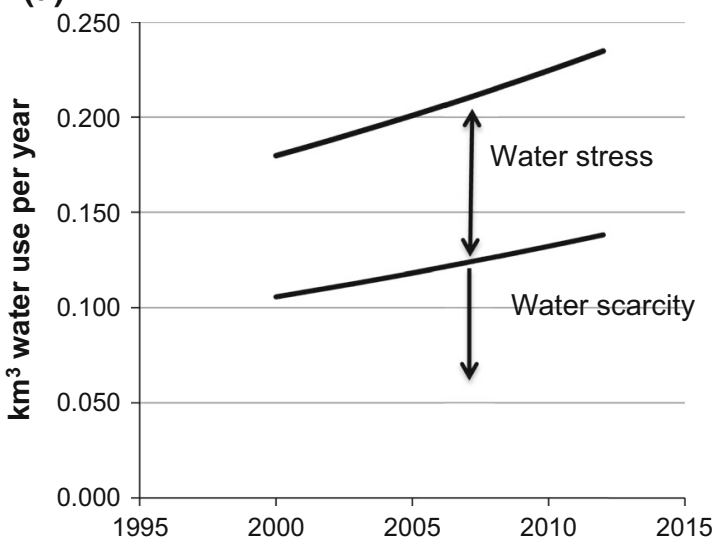

(b)

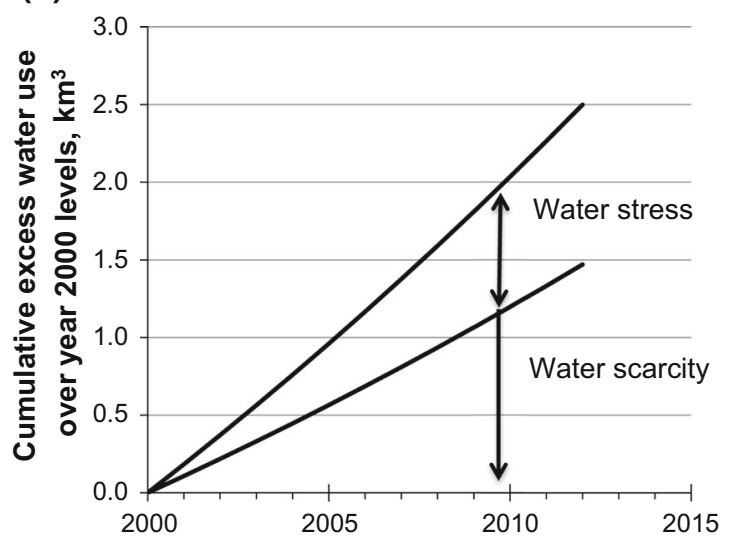

Fig. 12 Population growth and resulting water use. a For a $2.2 \%$ increase in population, water use increase is greater for water consumption at "water stress" levels of water use than at "water scarcity" levels of water use. This is for the population estimated to be served by karezes in six districts in Kandahar Province (see text).

\section{Summary}

An ancient water supply system, called kariz in Afghanistan, has supplied, until recently, low-cost and well-timed water to rural families and family groups in Afghanistan. A kariz is a sub-horizontal tunnel that is hand-dug in alluvial fans flanking the Hindu Kush. An average kariz is about $1 \mathrm{~km}$ long and $1 \mathrm{~m}^{2}$ in cross-section in Afghanistan, with vertical access shafts visible in many kinds of remotely sensed images. The tunnels have gradients of about $1 \mathrm{~m} \mathrm{~km}^{-1}$, allowing gravity flow of water that minimizes damage to the structure by physical erosion of the tunnel floor and walls. Recently, many of these karezes have gone dry. Preservation of the water supply, as well as of the cultural significance of these old structures, provides a justification for a deeper understanding of how they function to produce water. This study includes modeling the delivery of water to a theoretical kariz using Visual MODFLOW, with a representative kariz discharge rate as a means of calibrating the model. Our work shows that a successful model is strongly controlled by choice of hydraulic conductivity (for simulations in this study, $70 \mathrm{~m} \mathrm{day}^{-1}$ was optimal), the ratio of kariz hydraulic conductivity to aquifer conductivity $\left(10^{7}\right.$ was optimal in this study), as well as the length of the kariz in contact with the water table. Further, the natural water discharge from the kariz to surface canals was successfully simulated using a pumping well at the downgradient end of the kariz. Many other factors remain in need of investigation, including (1) simulations of a heterogeneous hydraulic conductivity domain more representative of alluvial fan depositional system; (2) a better realization of alluvial aquifer recharge through influent rivers carrying seasonal snowmelt from the

b From 2000 to 2012, approximately $2.5 \mathrm{~km}^{3}$ of water would be consumed by the population growth in the six-district area near Kandahar (see text) if consumption was at the water stress level, or a little more than $1.5 \mathrm{~km}^{3}$ if at the water scarcity level

Hindu Kush; (3) a better simulation of the water loss when the kariz tunnel lies above the water table, but is still belowground; (4) a thorough investigation of the capture zone of a kariz; and (5) the potential influence of traditional pumped vertical water wells (tube wells) on kariz discharge rates.

The gentle gradient of the kariz makes it particularly vulnerable to reduction in recharge of alluvial fan aquifers. Water production from karezes with a typical gentle slope $\left(1 \mathrm{~m} \mathrm{~km}^{-1}\right)$ over $1 \mathrm{~km}$ length suggests a decrease in watertable elevation of $1 \mathrm{~m}$ will result in no kariz water discharge unless the kariz tunnel is deepened. Deepening of the tunnel is likely constrained by engineering principles of tunnel stability in unconsolidated materials.

Climate trends in Afghanistan are difficult to document because of many years of military conflict resulting in discontinuous and/or destroyed records. Some data suggest warming has already occurred in the region over at least the past from the 1960s through at least 2000, and IPCC predictions suggest warming in the future although the predictions come with high levels of uncertainty. Multidecadal trends also show decreasing snow cover in the region, a particularly alarming result because the alluvial fan aquifers supplying water to the karezes depend upon recharge from snowmelt-fed, influent rivers. Besides aquifer recharge, increasing water use probably has affected groundwater supplies: population-growth rates of $2.2 \%$ over the past two decades predict significant increases in water demand, even at levels described by the UN as water stress or water scarcity. For the period 2000-2012, an estimate of water consumption caused by population increase in six districts in Kandahar Province where karezes are likely the major source of water shows that watertable levels could have decreased by $0.8-5.6 \mathrm{~m}$, depending 
on aquifer porosity and level of water use. This shows that, even at the highest porosity, which causes the smallest decrease in the water-table level, karezes are likely to have greatly reduced water production. Therefore, kariz-supplied water in southern Afghanistan is likely unsustainable under current conditions of population growth and observed and predicted climate change.

Acknowledgments This project was funded by the US Army Research Office through awards W911NF-10-1-0232 and W911NF11-1-0035. We are grateful for support from the KU Geology Associates Fund of the KU Endowment Association, and the KU Depts. of Geology, Geography, and Graduate Military Education. We thank the reviewers who helped to improve this manuscript. The following information individuals provided valuable information for this project, for which we are grateful: Jubal Grubb (Captain, US Army), Ted Angle (Captain, US Army), Kyle Kirschenmann (Hydrologist/PM/ PPO, Civilian Expeditionary Workforce), Chad Nichols (hydrogeologist, 30th Naval Construction Regiment), Julie Kelley (US Army ERDC), Bill Steele (Petty Officer First Class, USN Reserve). We also thank J.F. Devlin for assistance with computer modeling conceptualization early in the project, Melissa Goldade for GIS mapping, and Carla Whisner for early attempts at modeling the kariz. Kevin Dobbs assisted with GIS data compilation and imaging.

Open Access This article is distributed under the terms of the Creative Commons Attribution 4.0 International License (http:// creativecommons.org/licenses/by/4.0/), which permits unrestricted use, distribution, and reproduction in any medium, provided you give appropriate credit to the original author(s) and the source, provide a link to the Creative Commons license, and indicate if changes were made.

\section{References}

Akbari M, Tahir M, Litke DW, Chornack MP (2007) Ground-water levels in the Kabul Basin, Afghanistan, 2004-07. U.S. Geological Survey Open File Report 2007-1294, p 45

Amin MI, Qazi R, Downing TE (1983) Efficiency of infiltration galleries as a source of water in arid lands. Wat Int 8(4):158-165. doi:10.1080/02508068308686034

Banks D, Soldal O (2002) Towards a policy for sustainable use of groundwater by non-governmental organisations in Afghanistan. Hydrogeol J 10(3):377-392. doi:10.1007/s10040-002-0203-y

Barlow MA, Tippett MK (2008) Variability and predictability of Central Asia river flows: antecedent winter precipitation and large-scale teleconnections. J Hydrometeorol 9:1334-1339

Beaumont P (1973) A traditional method of groundwater extraction in the Middle East. Ground Water 11(5):23-30

Beaumont P (1989) The qanat: a means of water provision from groundwater sources. In: Beaumont P, Bonine M, McLachlan K, McLachlan A (eds) Qanat, kariz, and khattara: traditional water systems in the Middle East and North Africa. School of Oriental and African Studies, University of London, London, pp 13-31

Blair TC, McPherson JG (1994) Alluvial fans and their natural distinction from rivers based on morphology, hydraulic processes, sedimentary processes, and facies assemblages. J Sediment Res 64(3):450-489

Broshears RE, Akbari M, Chornack MP, Mueller DK, Ruddy BC (2005) Inventory of ground-water resources in the Kabul Basin, Afghanistan. US Geological Survey Scientific Investigations Report 2005-5090, p 34
Campbell J (2015) A dry and ravaged land: investigating water resources in Afghanistan. Earth Mag 60(1-2):48-55

CDM (2003) Kandahar groundwater resource assessment. Final Report to USAID/Kabul, Contract No. LAB-I-00-98-00034-00 Task Order \#806, p 40, (20 unnumbered pages of figures)

CIA (2011) The world factbook. https://www.cia.gov/library/ publications/the-world-factbook/fields/2002.html. Accessed 9 Apr 2013

CIA (2012) The world factbook. https://www.cia.gov/library/ publications/the-world-factbook/fields/2002.html. Accessed 9 Apr 2013

Cressey GB (1958) Qanats, karez, and foggaras. Geogr Rev 48(1):27-44

Doebrich JL, Wahl RR (2006) Geologic and mineral resource map of Afghanistan. USGS and AGS Open-File Report 2006-1038, version 2

English PW (1968) Spread of qanats in the old world. Proc Am Philos Soc 112(3): 170-181

ERDC (2002) Water resources areal appraisal of Afghanistan. Army Engineering Research and Development Center, Vicksburg MS (USA) 52 p

FAO (1996) Afghanistan, promotion of agricultural rehabilitation and development programmes, water resources and irrigation. FAO (Food and Agricultural Organization of the United Nations) Project TCP/AFG/4552, Afghanistan Research and Evaluation Unit

Favre R, Kamal GM (2004) Watershed atlas of Afghanistan, working document for planners, parts I and II 1st edn. Kabul: Government of Afghanistan, Ministry of Irrigation. Water Resources and Environment, p 60

FHCRAA (Future Harvest Consortium to Rebuild Agriculture in Afghanistan) (2002) Needs assessment on soil and water in Afghanistan. Coordinated by the Center for Agricultural Research in the Dry Areas (ICARDA), Aleppo, Syria; sponsored by the United States Agency for International Development, p 96

Frei A, Tedesco M, Lee S, Foster J, Hall DK, Kelly R, Robinson DA (2012) A review of global satellite-derived snow products. Ad Space Res 50(8):1007-1029. doi:10.1016/j.asr.2011.12.021

Gleick PH (1996) Basic water requirements for human activities: meeting basic needs. Water Int 21:83-92

Haritashya UK, Bishop MP, Shroder JF, Bush AB, Bulley HN (2009) Space-based assessment of glacier fluctuations in the Wakhan Pamir, Afghanistan. Clim Change 94(1-2):5-18

Hijioka Y, Lin E, Pereira JJ, Corlett RT, Cui X, Insarov GE, Lasco RD, Lindgren E, Surjan A (2014) Asia. In: Barros VR, Field CB, Dokken DJ, Mastrandrea MD, Mach KJ, Bilir TE, Chatterjee M, Ebi KL, Estrada YO, Genova RC, Girma B, Kissel ES, Levy AN, MacCracken S, Mastrandrea PR, White LL (eds) Climate change 2014: impacts, adaptation, and vulnerability. Part B: regional aspects. Contribution of Working Group II to the Fifth Assessment Report of the Intergovernmental Panel on climate change. Cambridge University Press, Cambridge, pp 1327-1370

Houben G, Niard N, Tünnermeier T, Himmelsbach T (2009a) Hydrogeology of the Kabul Basin (Afghanistan), part I: aquifers and hydrology. Hydrogeol J 17(4):665-677

Houben G, Tünnermeier T, Eqrar N, Himmelsbach T (2009b) Hydrogeology of the Kabul Basin (Afghanistan), part II: groundwater geochemistry. Hydrogeol J 17(4):935-948

Humlum J (1959) La géographie de l'Afghanistan. Etude d'un pays aride. Scandinavian University Books, Oslo

Hussain I, Abu-Rizaiza OS, Habib MA, Ashfaq M (2008) Revitalizing a traditional dryland water supply system: the karezes in Afghanistan, Iran, Pakistan and the Kingdom of Saudi Arabia. Water Int 33(3):333-349. doi:10.1080/ 02508060802255890

Jentsch C (1970) Die kareze in Afghanistan. Erkunde 24(2):112-120 
Kahlown MA, Hamilton JR (1994) Status and prospects of karez irrigation. Water Resour Bull 30(1):125-134

Kahlown MA, Khalil M, Munir M (1988) Karez irrigation in Baluchistan, bench mark study. Pakistan Water and Power Development Authority, October 1988, Irrigation Systems outside the Indus Basin, sub-project of Irrigation Systems Management Research Project, Government of PakistanUSAID Project, Planning Directorate (South) P\&I, WAPDA, p 216

Kakar K, Wahidi H et al (2011) Afghanistan human development report 2011, The forgotten front: water security and the crisis in sanitation. Centre for Policy and Human Development, Kabul University, Kabul, p 238

Khan MJ, Pacha G, Khattak MS, Oad R (2015) Water distribution of traditional karez irrigation systems in Afghanistan. Irrig Drain 64(2):169-179. doi:10.1002/ird.1890

Klein Tank AMGK et al (2006) Changes in daily temperature and precipitation extremes in central and south Asia. J Geophys Res Atmos 111:D16105. doi:10.1029/2005JD006316

Lightfoot D (2009) Survey of infiltration karez in northern Iraq: History and current status of underground aqueduct. Report prepared for UNESCO, IQ/2009/SC/RP/1, p 56

Livingston IS, O'Hanlon M (2012) Afghanistan index, also including selected data on Pakistan. Brookings tracks reconstruction and security in Afghanistan, Iraq and Pakistan, Brookings, Washington. http://www.brookings.edu/ /media/Programs/foreignpolicy/afghanistan-index/index20120516.pdf. Accessed 28 Aug 2013

Mack TJ, Akbari MA, Ashoor MH, Chornack MP, Coplen TB, Emerson DG, Hubbard BE, Litke DW, Michel RL, Plummer LN, Rezai MY, Senay GB (2010a) Conceptual model of water resources in the Kabul Basin, Afghanistan. US Geological Survey Scientific Investigations Report 2009-5262, p 240

Mack TJ, Chornack MP, Coplen TB, Plummer LN, Rezai MT, Verstraeten IM (2010b) Availability of water in the Kabul Basin, Afghanistan: US Geological Survey Fact Sheet 2010-3037, May 2010

Mack TJ, Chornack MP, Taher MR (2013) Groundwater-level trends and implications for sustainable water use in the Kabul Basin, Afghanistan. Environ Syst Decis 33:457-467. doi:10.1007/ s10669-013-9455-4

Makhmadaliev B, Kayumov A, Novidov V, Mustaeva N, Rajabov I (eds) (2008) The second national communication of the Republic of Tajikistan under the United Nations framework convention on climate change, Dushanbe, $\mathrm{p} 89$

Mannig B, Müller M, Starke E, Merkenschlager C, Mao W, Zhi X, Podzun R, Jacob D, Paeth H (2013) Dynamical downscaling of climate change in Central Asia. Glob Planet Change 110:26-39. doi:10.1016/j.gloplacha.2013.05.008

Mays LW (2008) A very brief history of hydraulic technology during antiquity. Environ Fluid Mech 8:471-484. doi:10.1007/s10652008-9095-2

McClymonds NE (1972) Shallow ground water in the Zamin Dawar area, Helmand Province, Afghanistan. U.S. Geological Survey Open-File Report 73-166, p 103

McGuire VL (2012) Water-level and storage changes in the High Plains aquifer, predevelopment to 2011 and 2009-11. US Geological Survey Scientific Investigations Report 2012-5291, p 15

McLachlan K (1989) The kariz in the Herat Basin, Afghanistan. In: Beaumont P, Bonine ME, McLachlan KS, McLachlan A (eds) Qanat, kariz, and khattara: traditional water systems in the Middle East and North Africa. School of Oriental and African Studies, University of London, London, pp 257-266
Milly PCD, Dunne KA, Vecchia AV (2005) Global pattern of trends in streamflow and wateravailability in a changing climate. Nature 438:347-350

Nasrallah HA, Balling RC Jr (1993) Spatial and temporal analysis of Middle Eastern temperature changes. Clim Change 25:153-161

Oosterbaan RJ (1982) Modern interferences in traditional water resources in Baluchistan. Annual Report, International Institute for land reclamation and improvement, Wageningen, $\mathrm{p} 23-33$

Reading HG (ed) (1978) Sedimentary environments: processes, facies and stratigraphy. Wiley, New York

Remini B, Achour B, Albergel J (2014) The qanat of Algerian Sahara: an evolutionary hydraulic system. Appl Water Sci. doi:10.1007/ s13201-014-0195-5

Robinson DA, Frei A (2000) Seasonal variability of northern hemisphere snow extent using visible satellite data. Prof Geogr 51:307-314

Robinson DA, Dewey KF, Heim RR Jr (1993) Global snow cover monitoring: an update. Bull Am Meteorol Soc 74:1689-1696

Rout B (2008) How the water flows: a typology of irrigation systems in Afghanistan. Afghanistan Research and Evaluation Unit Issue Paper, Series: Water management, livestock and the opium economy, Kabul, p 57

Sarikaya MA, Bishop MP, Shroder JF, Olsenholler JA (2012) Spacebased observations of Eastern Hindu Kush glaciers between 1976 and 2007, Afghanistan and Pakistan. Remote Sens Lett 3(1):77-84

Scanlon BR, Keese KE, Flint AL, Flint LE, Gaye CB, Edmunds WM, Simmers I (2006) Global synthesis of groundwater recharge in semiarid and arid regions. Hydrol Process 20:3335-3370. doi:10. 1002/hyp.6335

Schiemann R, Lüthi D, Vidale PL, Schär C (2008) The precipitation climate of Central Asia-intercomparison of observational and numerical data sources in a remote semiarid region. Int $\mathrm{J}$ Climatol 28:295-314. doi:10.1002/joc.1532

Schlumberger (2009) Visual MODFLOW 2009. Schlumberger Water Services, Waterloo Hydrogeologic Inc, Waterloo

Shobair SS (2002) Current drought situation in Afghanistan. FAO Afghanistan

Shobair SS, Alim AK (2004) The effects of calamities on water resources and consumption in Afghanistan. Joint report of FAO and WHO in Afghanistan, p 11

Shroder JF (2014) Natural resources of Afghanistan. Elsevier, Amsterdam

Silliman SE, Boukari M, Crane P, Azonsi F, Neal CR (2007) Observations on elemental concentrations of groundwater in central Benin. J Hydrol 335:374-388

Syed FS, Giorgi F, Pal JS, King MP (2006) Effect of remote forcings on the winter precipitation of central southwest Asia, part 1: observations. Theor Appl Climatol 86:147-160. doi:10.1007/ s00704-005-0217-1

Tünnermeier T, Houben G, Himmelsbach T (2005) Hydrogeology of the Kabul Basin, part i: geology, aquifer characteristics, climate and hydrography. BGR Record number 10277/05, p 46

Uhl VW (2006) Afghanistan: an overview of ground water resources and challenges. Ground Water 55(5):626-627

Uhl VW, Tahiri MQ (2003) Afghanistan: an overview of groundwater resources and challenges. Uhl, Baron, Rana \& Associates, Washington Crossing PA, p 60

Unger-Shayesteh K, Vorogushyn S, Farinotti D, Gafurov A, Duethmann D, Mandychev A, Merz B (2013) What do we know about past changes in the water cycle of Central Asian headwaters? A review. Glob Planet Change 110:4-25. doi:10.1016/j.gloplacha. 2013.02.004 
Vining KC, Vecchia AV (2007) Water-balance simulations of runoff and reservoir storage for the Upper Helmand watershed and Kajakai Reservoir, Central Afghanistan. US Geological Survey Scientific Investigations Report, 5148, p 16

UN Water (2013) International decade for action, "Water for Life", 2005-2015. http://www.un.org/waterforlifedecade/scarcity.shtml. Accessed 24 Dec 2014
Whitney JW (2006) Geology, water, and wind in the lower Helmand Basin, Southern Afghanistan. US Geological Survey Scientific Investigations Report, 2006-5182, p 40

Yousefirad M, Mokhtar S, Mahbod A (2012) The influential factors on the qanat hydrogeology. J Food Agric Environ 10(2):843-848 